\title{
ADB OPERATIONS IN THE
}
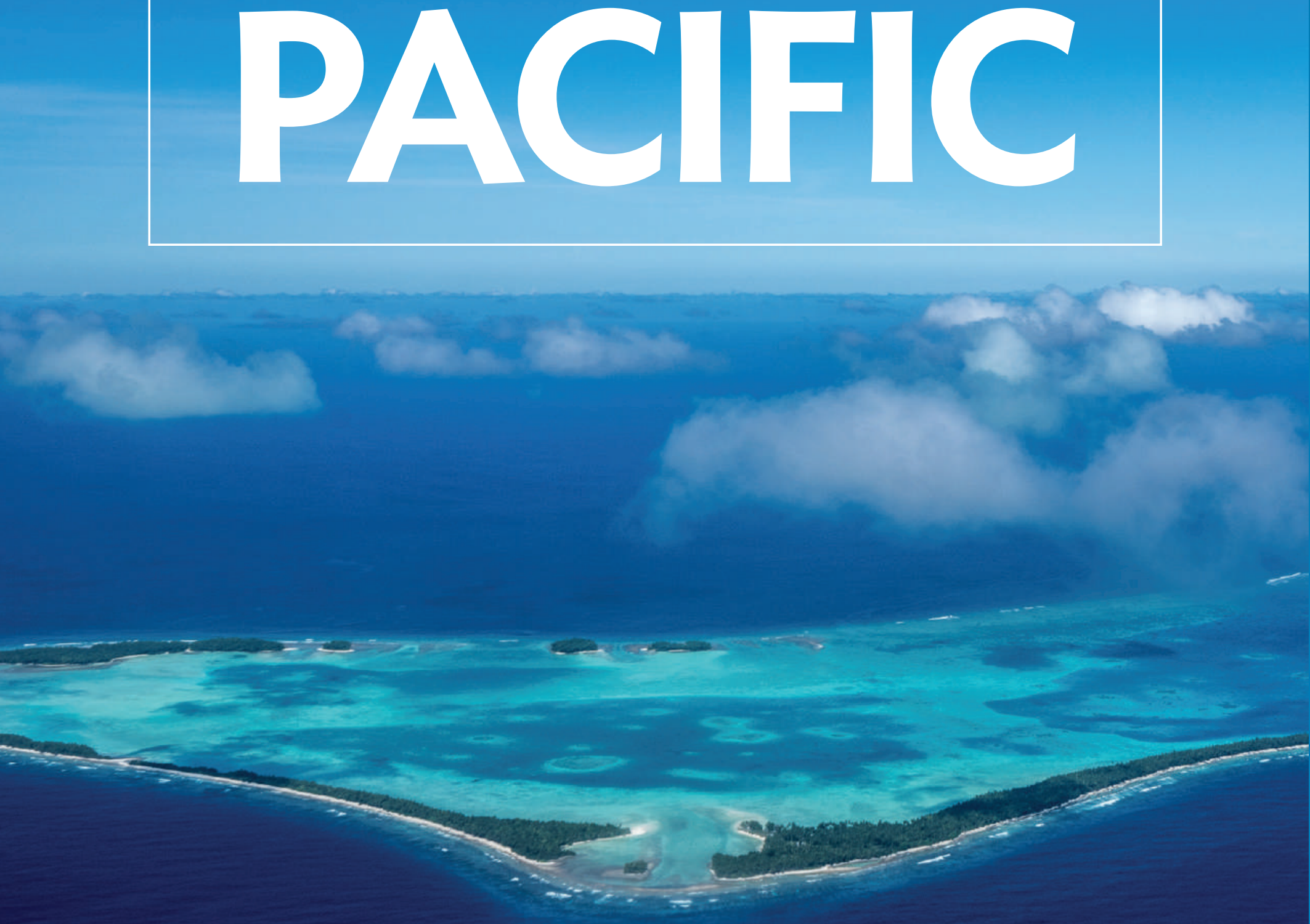

$\mathrm{ADB}$ 


\section{TIMELINE OF KEY EVENTS AND MILESTONES IN THE PACIFIC, 1966-2019}

1966

Samoa joined ADB as the first Pacific island developing member country.

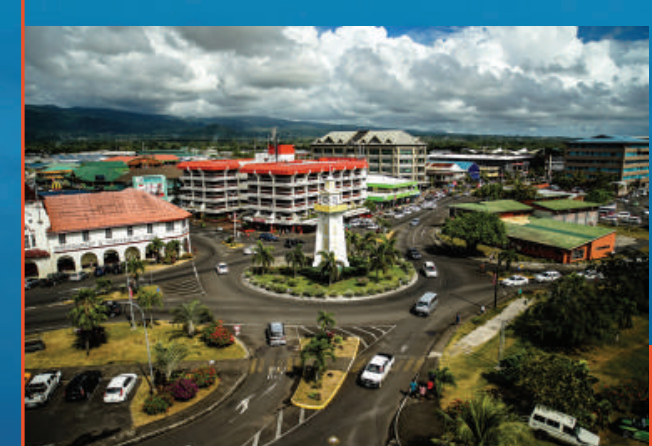
1966-1976

\section{9}

The first ADB-Samoa loan for the Samoa approved.

1970

Fiji joined ADB.

1971

Papua New Guinea joined ADB; South Paciffc

1972

Tonga joined ADB.

1973

Solomon Islands
joined ADB.

1974

Kiribati joined ADB

1976

The Cook Islands

\section{9} Fisheries Agency was Survey 1979: Pacific Agriculture, Choices and Constraints was published.

ADB approved its first multiproject loan for Tonga (\$1.2 million), a

\section{7-1986}

\section{0}

Guidelines for ADB's Pacific were established.

\section{1}

Vanuatu joined ADB.

\section{2}

The Secretariat of Environment Programme was established.

\section{4} in Port Vila, Vanuatu.
The Pacific Islands Forum

South Pacific Agricultural small island economies. operations in the agriculture sector in the ADB's South Pacific and Programs for Sustainable Regional Mission opened

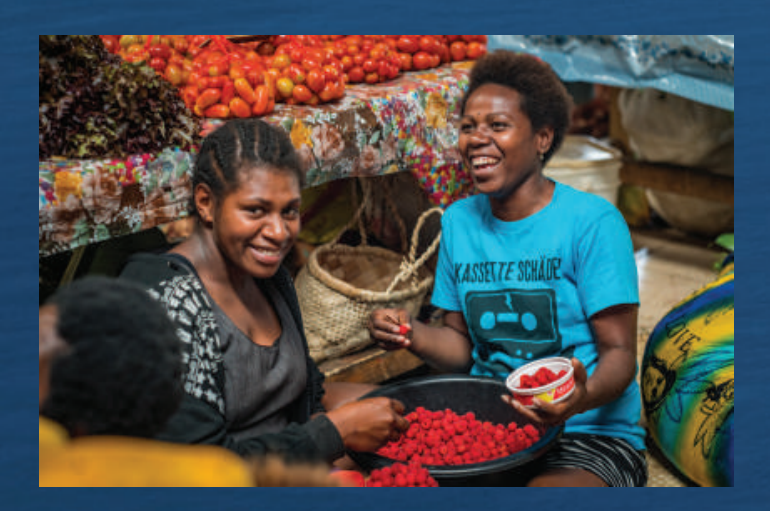

ADB's first regional strategy
1997

1998

The Special Mission in Papua and became an extended miss in 1999 , and a resident mission in 2002 .

1990

The Marshall Islands and the Federated States of

\section{0}

1991

Nauru joined ADB.

1993

Tuvalu joined ADB.

1987-1996

\section{4}

The United Nations Convention on the Law of the Sea came

\section{5}

ADB's Office of Pacific

Operations was established to enhance the country focus of its operations in the Pacific. Growth - was prepared.

ADB's first economic reportHiuman Resource Development: was published.

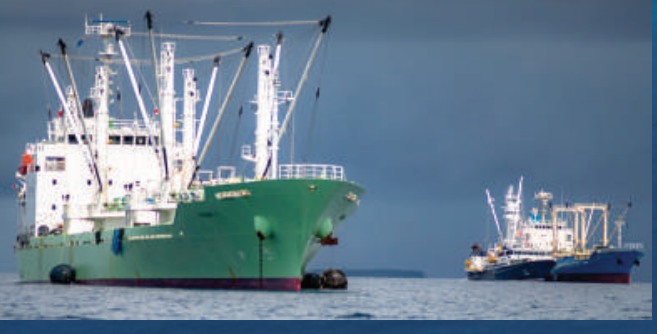

East Timor was established, a resident mission in 2013.

\section{7-2006}

\section{2}

Timor-Leste joined ADB.

\section{3}

ined ADB.

\section{4} was established in Sydney.

\section{5}

gration was approved by the
The South Pacific Commission changed its name to Pacific

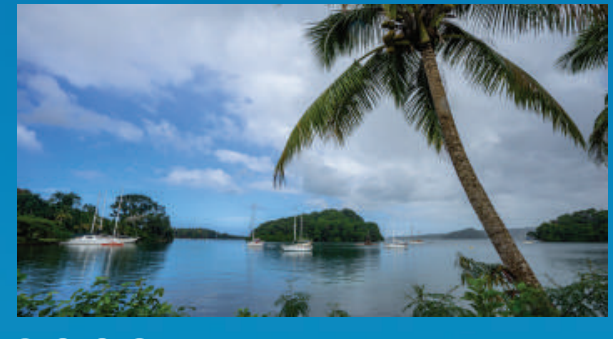

\section{9}

Joint ADB and World Bank development coordination offices in Samoa, Solomon Ist
were established.

\section{0}

ADB's regional strategy, Pacific Approach 2010-2014, was prepared, and emphasized strengthened regional cooperation.

Joint ADB and World Bank development coordination offices in the Cook Islands, Kiribati, the Marshall lslands, the Federated Vanuatu were established.

became a Special Office in

The Pacific Subregional Office was established in Suva and the Pacific

The Pacific Plan for Strengthening

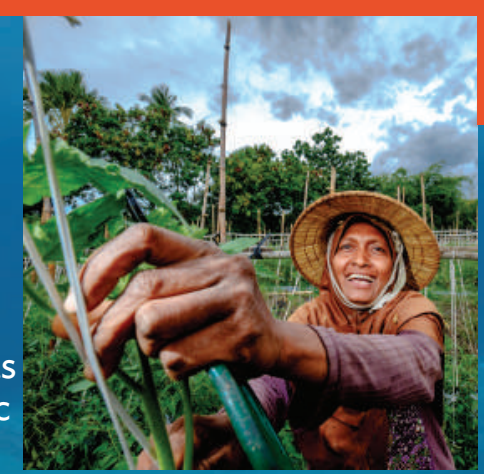

\section{7-2019}

\section{5}

Extended missions in Samoa Vanuatu were established.

\section{6}

ADB's regional strategy, Pacific Approach 2016-2020, focuses on reducing costs, managing risks, and

\section{8}

ADB approved the establishment Pacific developing member countries.

\section{9}

Niue joined ADB.

ADB's 52nd Annual Meeting was

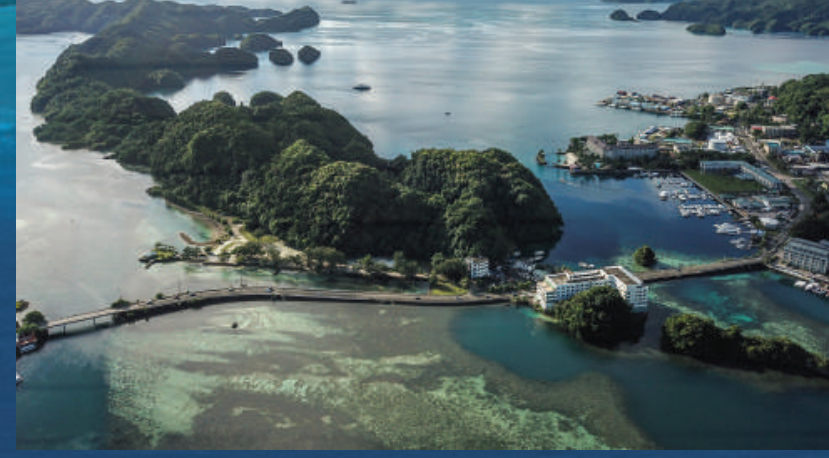




\section{CONTENTS}

Foreword

Overview

Transport

Energy

Health

Water and Urban Development

Public Sector Management

ADB Ongoing Operations in the Pacific

Information and Communication Technology

Education

Private Sector Development

Climate Change and Disaster Risk Management

Gender Inclusiveness

Regional Cooperation and Integration

Cofinancing

Knowledge Sharing and Capacity Development

Partnerships

ADB Offices in the Pacific 


\section{ADB OPERATIONS IN THE PACIFIC}

Fiji is the host of the 52nd Annual Meeting of the Board of Governors of the Asian Development Bank (ADB) in May 2019. This is the first time one of ADB's Pacific developing member countries (DMCs) is hosting the Annual Meeting, and ADB is commemorating the event with a special publication on its operations in the Pacific.

When ADB was established in 1966, its founders included a provision in ADB's Charter that its smallest members deserve "special regard" in recognition of their unique circumstances. Recognizing their small populations, geographic isolation, and heightened vulnerability to natural disasters, ADB's development assistance to its Pacific DMCs responds to the unique conditions, challenges, and capacities of small island developing states. ADB's 15 Pacific DMCs require tailored development assistance that responds to local circumstances and constraints.

ADB's Pacific Approach 2016-2020 advocates a three-pronged strategy to assist Pacific DMCs in reducing costs, managing risks, and enabling value creation. A key focus of ADB's operations in the Pacific is reducing vulnerability by building resilience and strengthening local capacities to respond to external shocks, climate change, and disasters. The theme of addressing vulnerability is likewise reflected in ADB's Strategy 2030, which recognizes the need to apply a differentiated approach to development in small island developing states and in countries with fragile and conflict-affected situations.

To sustain this growth, ADB is expanding its physical presence in the Pacific. In September 2018, the ADB Board of Directors approved the establishment of country offices in the 11 Pacific DMCs, in addition to existing offices in Fiji, Papua New Guinea, and Timor-Leste.

Over the span of half a century, the Pacific has undergone tremendous change. From a region of only 3.6 million people in 1966, the population in the 15 Pacific DMCs now stands at almost 13 million. The average gross domestic product per capita in the Pacific now exceeds $\$ 2,500$ in real terms-a large jump from about $\$ 200$ 5 decades ago. Although there has been significant progress in improving access to basic services such as health, education, and safe water, reducing poverty remains a huge challenge, particularly in rural areas and outer islands.

ADB's operations in the Pacific began in 1969 with a \$2.4 million loan to Samoa for the Faleolo Airport. ADB's operations throughout the region have grown significantly since then, with cumulative financial assistance reaching $\$ 5.1$ billion at the end of 2018. ADB's Pacific portfolio of active loans and grants at year-end 2018 included 74 projects with a total value of $\$ 2.8$ billion.

This publication provides a snapshot of ADB's operations in the Pacific over the past five decades, highlighting recent examples of ADB's assistance activities in different sectors and thematic areas. We look forward to deepening our collaboration with our DMCs and development partners in the region, and building a better future for the people of the Pacific.

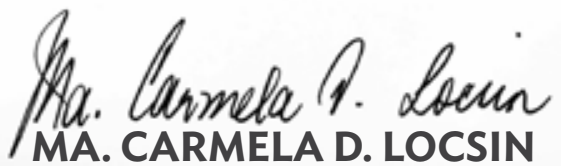

Director General

Pacific Department

Asian Development Bank 
ADB's Active Loans and Grants in the Pacific, 2005-2018

(Financing amount, inclusive of cofinancing, and number of projects)

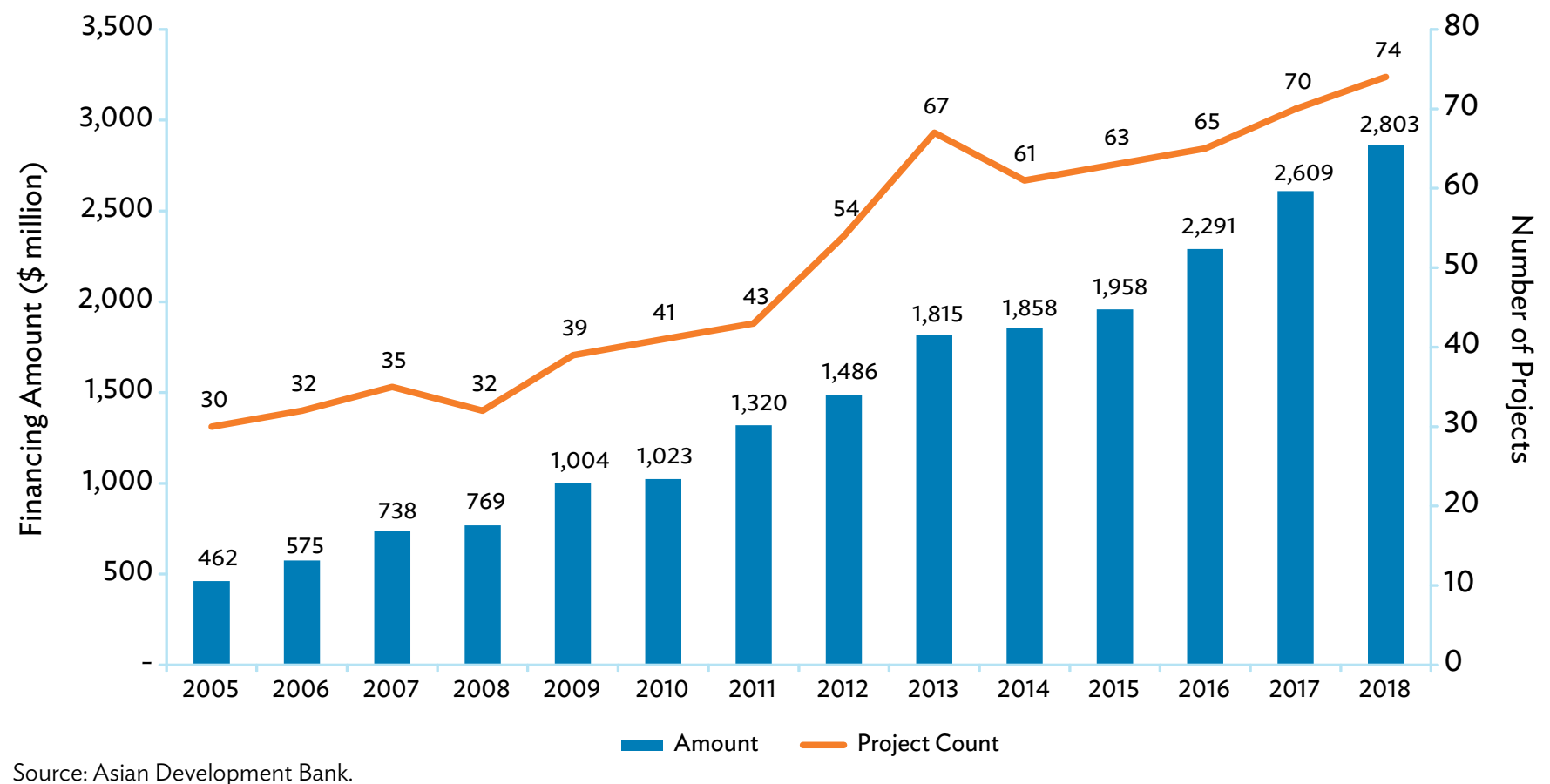

Active Loans and Grants by Country, 2018

(\% of total portfolio at year-end)

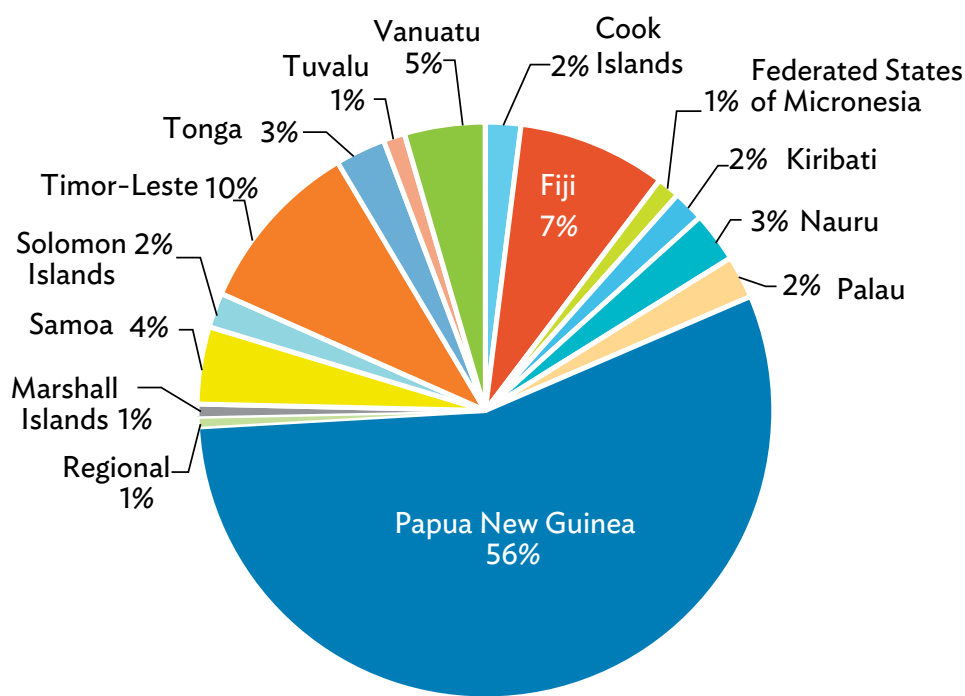

Source: Asian Development Bank.
Active Loans and Grants by Sector, 2018

(\% of total portfolio at year-end)

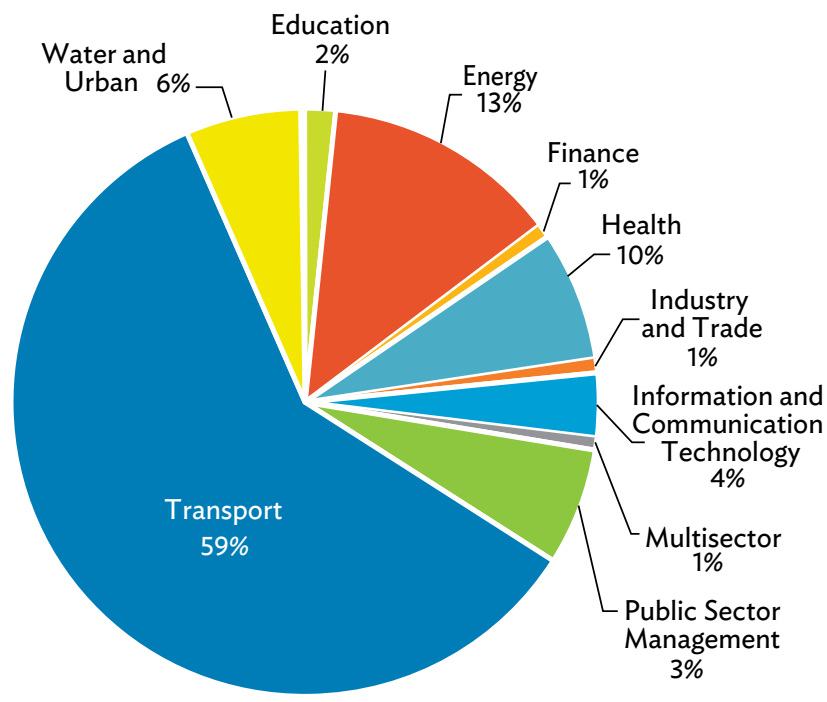

Source: Asian Development Bank. 


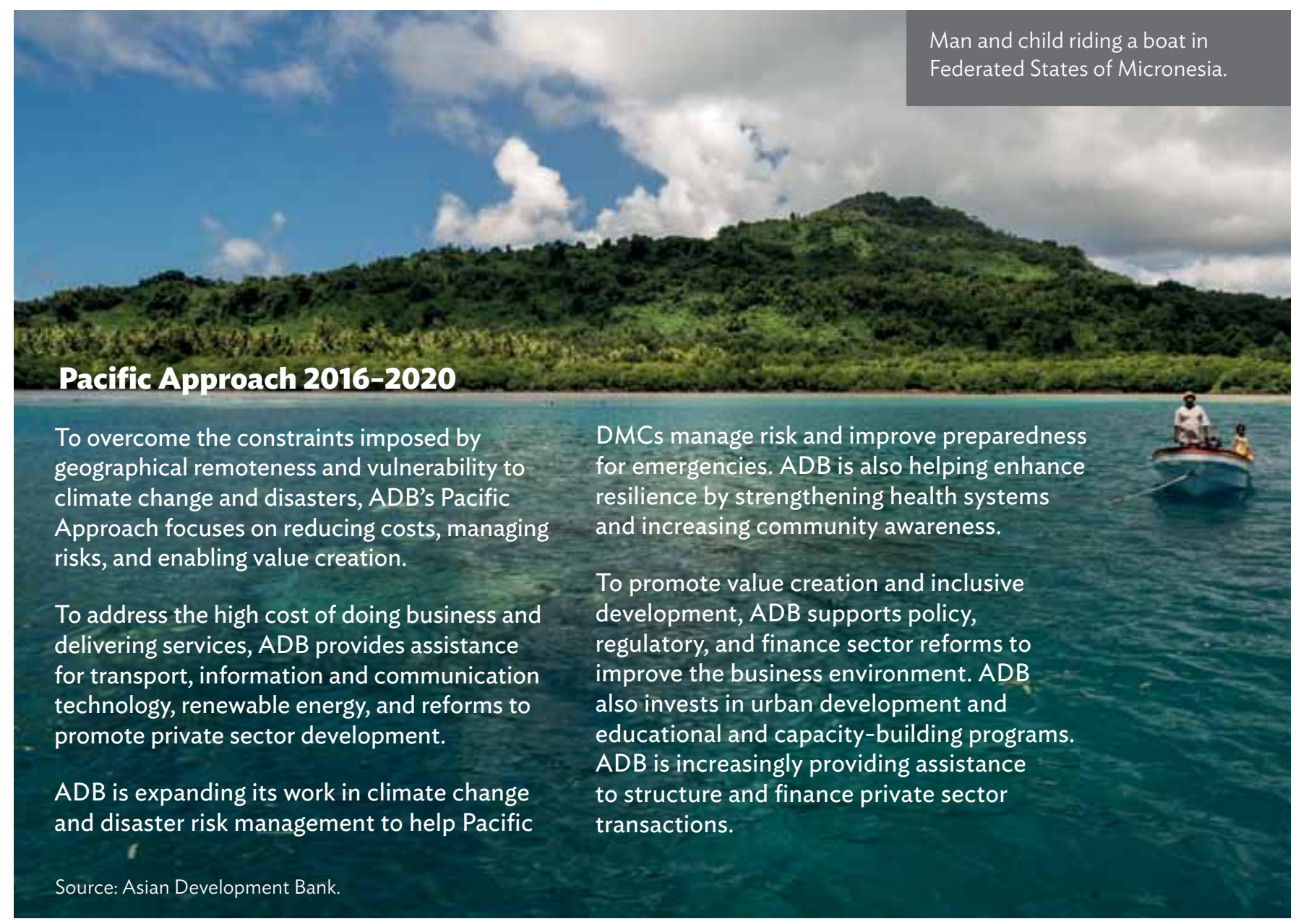

ADB Pacific Developing Member Countries

\begin{tabular}{lrrrr|} 
Country & Population & $\begin{array}{c}\text { Land Area } \\
(\mathrm{sq} . \mathrm{km} \text {. })\end{array}$ & $\begin{array}{c}\text { GDP Level } \\
\text { Year of Joining } \\
\text { ADB }\end{array}$ \\
\hline Cook Islands & 19,300 & 237 & $\$ 351$ million & 1976 \\
\hline Fiji & 889,900 & 18,270 & $\$ 5.2$ billion & 1970 \\
\hline Kiribati & 114,100 & 849 & $\$ 206$ million & 1974 \\
\hline Marshall Islands & 55,600 & 81 & $\$ 214$ million & 1990 \\
\hline Micronesia, Federated States of & 102,200 & 702 & $\$ 348$ million & 1990 \\
\hline Nauru & 13,000 & 27 & $\$ 110$ million & 1991 \\
\hline Niue & 1,600 & 261 & $\$ 25$ million & 2019 \\
\hline Palau & 18,400 & 508 & $\$ 299$ million & 2003 \\
\hline Papua New Guinea & $9,008,700$ & 462,840 & $\$ 24.2$ billion & 1971 \\
\hline Samoa & 199,200 & 2,842 & $\$ 873$ million & 1966 \\
\hline Solomon Islands & 688,700 & 28,400 & $\$ 1.2$ billion & 1973 \\
\hline Timor-Leste & $1,260,000$ & 15,007 & $\$ 1.6$ billion & 2002 \\
\hline Tonga & 104,800 & 717 & $\$ 427$ million & 1972 \\
\hline Tuvalu & 10,300 & 26 & $\$ 43$ million & 1993 \\
\hline Vanuatu & 304,400 & 12,190 & $\$ 904$ million & 1981 \\
\hline
\end{tabular}

$\mathrm{ADB}=$ Asian Development bank, GDP = gross domestic product.

Note: Population and GDP data are as of 2018, with the exception of Niue, for which data is as of 2016.

Source: Asian Development Outlook database, ADB Basic Statistics 2018, and ADB estimates. 



\section{OVERVIEW}

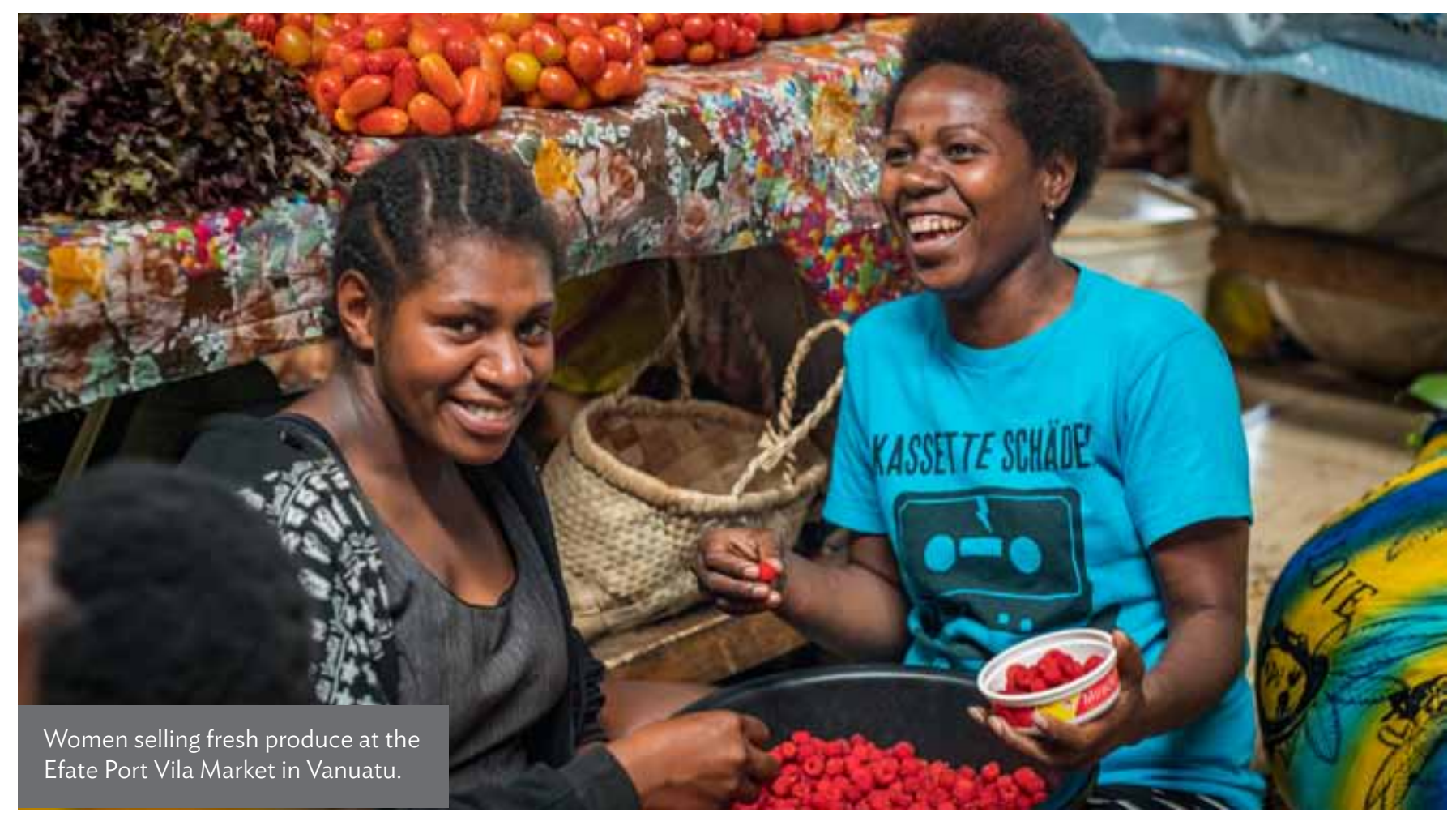

\section{ADB's Pacific Developing Member Countries}

The 15 Pacific developing member countries (DMCs) of the Asian Development Bank (ADB) include a founding member, Samoa, and ADB's newest member, Niue. Together, the Pacific DMCs cover a geographical area of 30 million square kilometers, although their combined landmass occupies only $2 \%$ of the entire area. The largest Pacific member is Papua New Guinea (PNG), with 9 million people. The other 14 Pacific DMCs have a combined population of about 3.8 million.

By income per capita, most Pacific island economies would be considered middle-income countries. However, goods and services generally cost much more in the Pacific, due in part to transport costs and small market sizes. Actual living standards are lower than the statistics indicate, especially in rural areas and outer island communities.

ADB's assistance to its Pacific DMCs has grown significantly over the past decade. The active portfolio of ADB projects expanded from less than $\$ 500$ million in 2005 to nearly $\$ 3$ billion at the end of 2018 .

\section{Development Constraints}

Separated by vast bodies of water, the Pacific DMCs are among the most isolated economies on the planet. Public and private sector organizations in the Pacific face huge challenges in delivering vital goods and services to their scattered populations, and the Pacific DMCs are also among the most vulnerable to climate change and disasters.

With the increasing number of extreme weather events globally, the Pacific DMCs have suffered from several severe cyclones in recent years. Since 2010, there have been more than 15 category 4 or category 5 cyclones in the region. Cyclone Pam hit Vanuatu in 2015, causing \$330 million in damages (equivalent to $46 \%$ of gross domestic product [GDP]); Cyclone Winston hit Fiji in 2016, causing $\$ 1.4$ billion in damages (equivalent to $31 \%$ of GDP); and Cyclone Gita hit Tonga in 2018, causing \$164 million in damages (equivalent to $36 \%$ of GDP).

\section{Main Areas of ADB Partnership}

In the initial decades of ADB's operations in the Pacific, agriculture and development banking were ADB's core areas of assistance. In recent years, transport, energy, water and urban development, and public sector management have become the main operational areas, with transport accounting for close to half of ADB's financing. 


\section{TRANSPORT}

Distance from major markets creates a unique set of challenges for providing essential goods and services in the Pacific, as well as for sustaining socioeconomic growth across the region. Improving connectivity through transport, trade, and information and communication technology (ICT) is essential for helping the Pacific DMCs overcome the challenges associated with their geographic isolation.

$A D B$ is helping increase transport connectivity by investing in land, maritime, and civil aviation infrastructure. By constructing and upgrading key transport links, ADB is connecting people with markets, jobs, and new opportunities.

\section{Achieving Results}

In the Pacific, ADB's transport sector operations have built or upgraded more than 1,000 kilometers of roads and bridges, and expanded or constructed 19 airports, 11 ports, and numerous wharves and jetties in small outer island communities. In addition, ADB has strengthened local capacities to carry out maintenance beyond project constructionensuring that key infrastructure is economically viable over its lifetime and creating jobs for local communities.

\section{Looking Forward}

Guided by ADB's Strategy 2030, transport will remain a priority sector for ADB's operations in the Pacific. ADB will continue introducing innovative transport solutions to create more efficient and sustainable transport connectivity, while strengthening institutions and driving reforms. ADB's forward operations will (i) finance sustainable transport infrastructure; (ii) support governments to prepare and implement sector strategies; (iii) introduce new technologies to improve operating efficiencies, lower life-cycle costs, promote environmentally sound designs, and improve safety; and (iv) expand cofinancing opportunities with development partners.

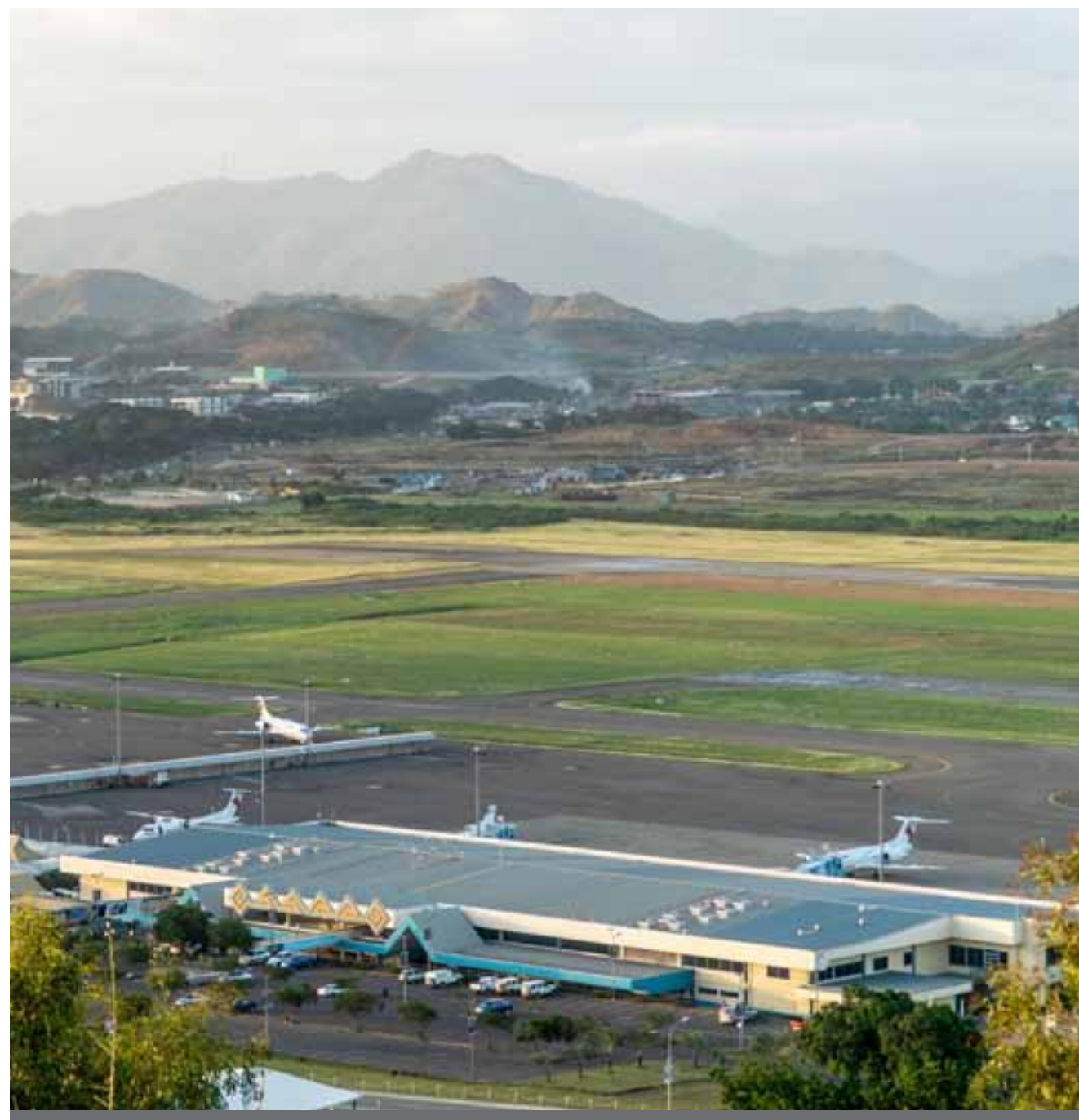

PNG Civil Aviation Development Investment Program. ADB is helping Papua New Guinea to develop a more efficient aviation network, which will move people and goods safely and reliably across the country's challenging terrain. The $\$ 480$ million investment program is upgrading 19 priority national airports, supporting institutional reforms, and building public and private sector capacities to use and maintain the airports and related infrastructure. 


\section{Kiribati Road}

Rehabilitation Project. In 2017, rehabilitation of the road network on South Tarawa, Kiribati's primary roadway, was completed. The total project cost of $\$ 69.2$ million was cofinanced by ADB, the Government of Australia, and the World Bank. The project rehabilitated 37.5 kilometers of paved road, installed safety features, and added more than 50 kilometers of footpaths. The upgraded roadway has improved safety conditions and socioeconomic opportunities for the residents of South Tarawa which is about $55 \%$ of the national population.

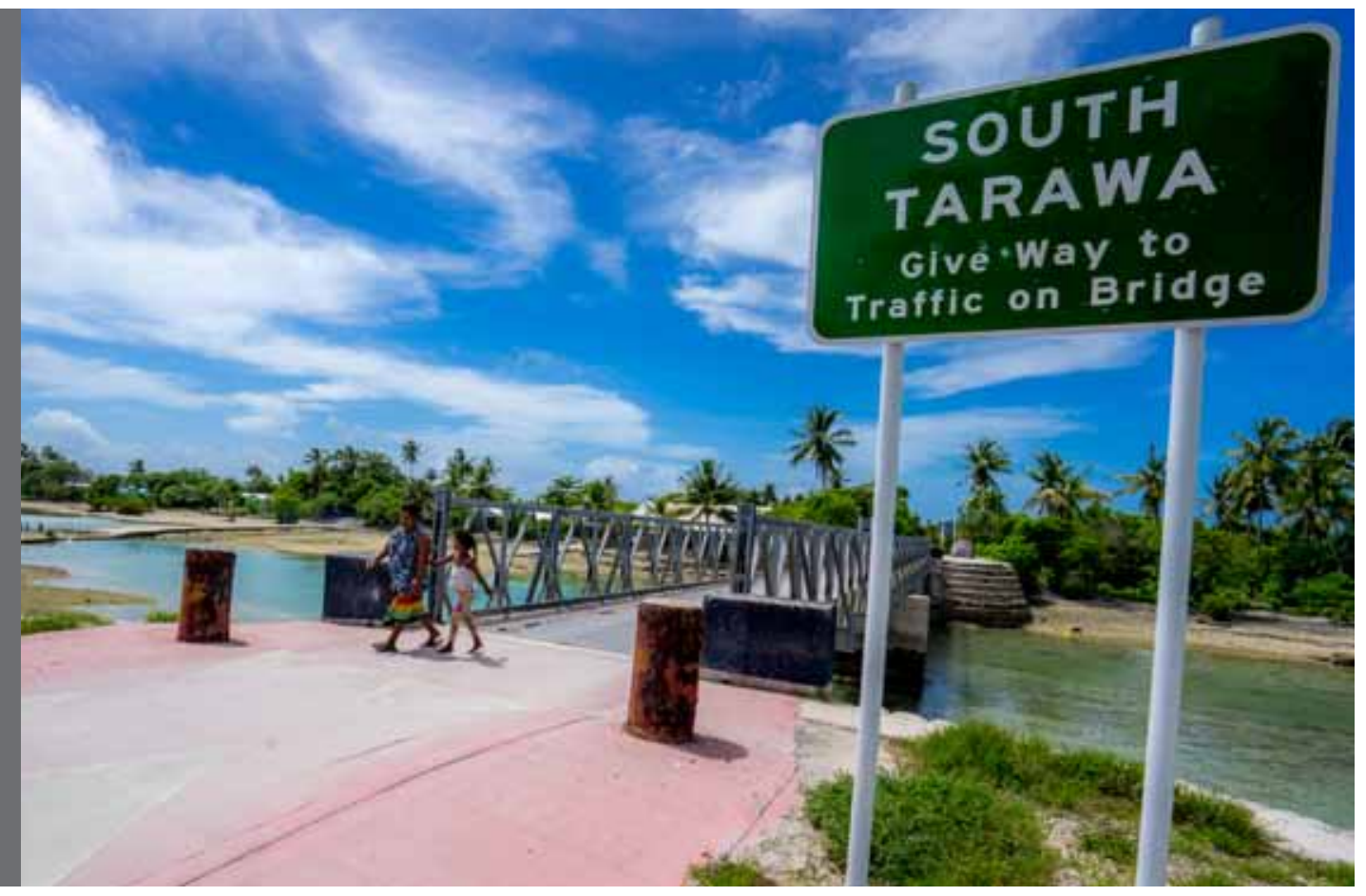

Nauru Sustainable and Climate Resilient Connectivity Project. ADB financing will help reconstruct and upgrade the country's primary commercial and transport hub, Aiwo Port. The project will reduce wait times for ships, decrease carbon dioxide emissions, lower import costs, and increase safety. The $\$ 86$ million project is jointly financed by ADB, the Government of Australia, the Government of Japan, the Government of Nauru, and the Green Climate Fund (GCF).

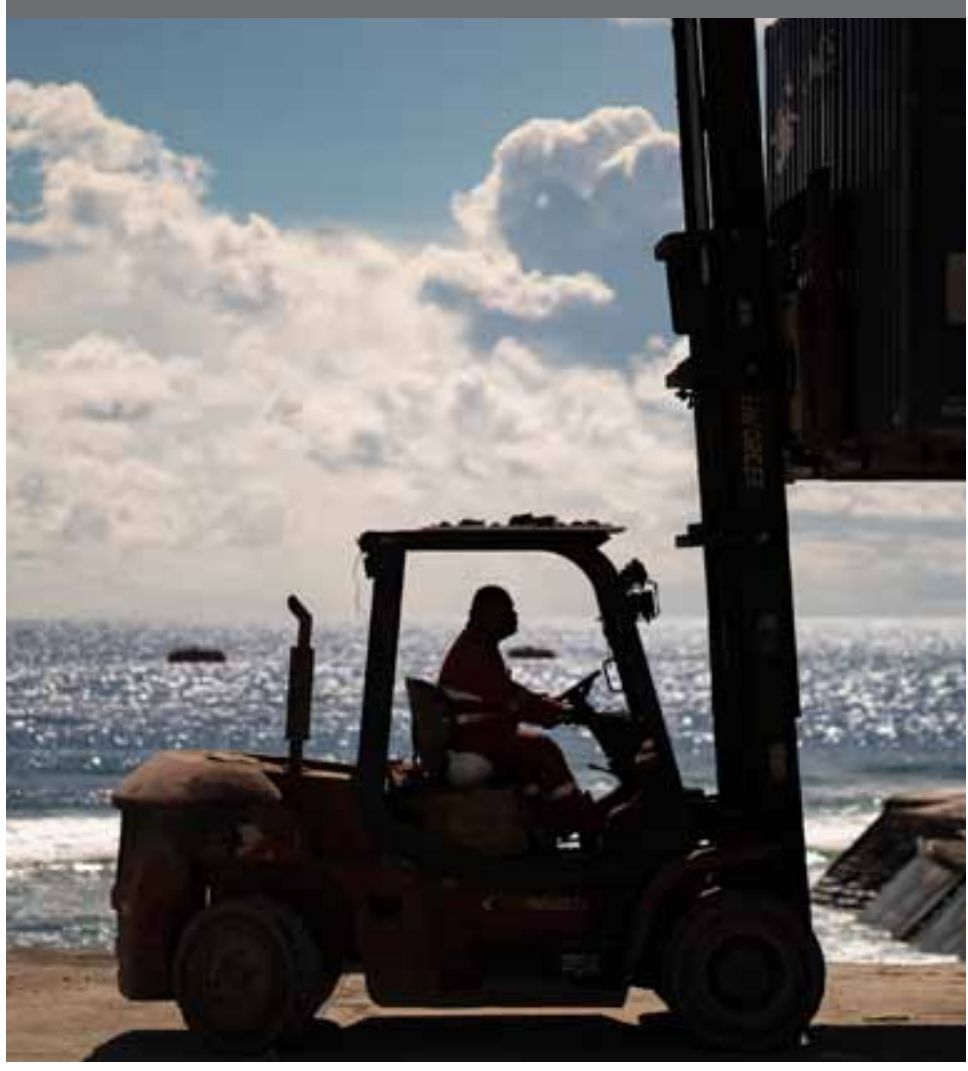

\section{TRANSPORT OPERATIONS}

AT A GLANCE

At the end of 2018, ADB's portfolio of active loans and grants for transport operations consisted of 23 projects with a total value of $\$ 1.7$ billion. The largest share of ADB support is for road improvement and upgrading, followed by air and sea transport development.

Total Volume of Active Transport Projects, by Country (\$ million, as of end-2018)

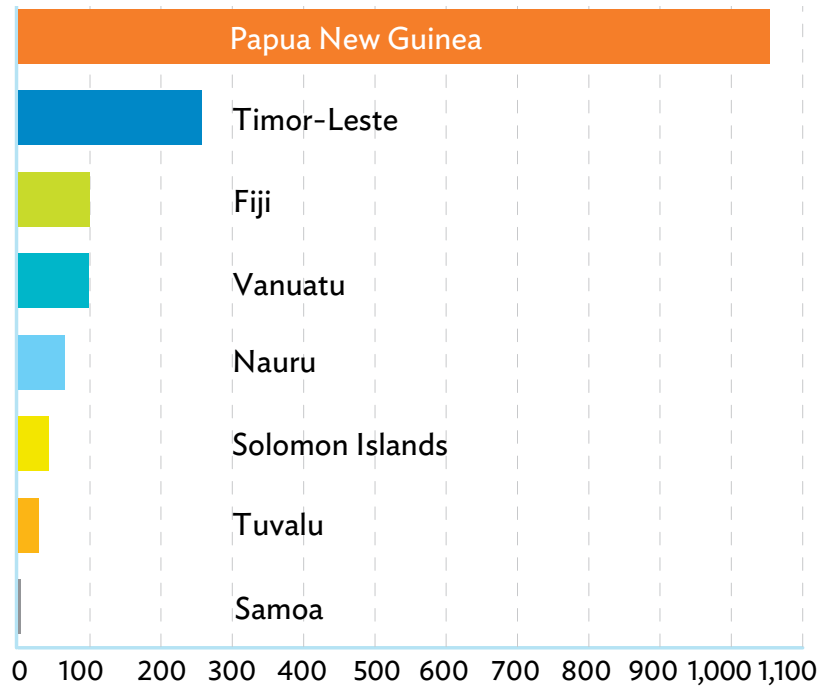

Source: Asian Development Bank. 
ADB's Pacific DMCs have embarked on a structural shift toward a renewable energy future, away from diesel power generation and targeting as much as $100 \%$ renewables for their energy mix. This transition is reducing dependency on imported fossil fuels, increasing access to affordable and reliable electricity, and supporting climate change mitigation by reducing carbon dioxide emissions.

To achieve their ambitious renewable energy goals, Pacific DMCs will require a significant increase in investment, as well as comprehensive sector reforms. ADB's energy program in the Pacific is responding to these needs by scaling up financing, and building human and institutional capacities.

ADB is financing solar, wind, hydropower, and battery storage as well as new transmission and distribution lines across the Pacific. Technical assistance is helping power utilities to operate more efficiently-with advisory services to improve financial management and corporate governance-through legal, policy, regulatory, and institutional reforms.

\section{Achieving Results}

From 2007 to 2018, ADB approved financing for projects to install 62 megawatts of renewable energy generation capacity, construct or refurbish more than $1,600 \mathrm{~km}$ of transmission and distribution lines, and connect more than 10,000 households to electricity grids.

ADB operations are increasing renewable energy generation capacities, reducing exposure to fuel price fluctuations, promoting private sector investments, and improving electricity delivery and sector efficiencies. For communities and businesses across the Pacific, the result is greater access to more affordable and reliable power.

\section{Looking Forward}

From 2019 through 2021, ADB's energy portfolio will roll out more than $\$ 1$ billion in energy investments across the region. This pipeline will finance transmission and distribution lines to connect households to electricity for the first time; install solar power, hydropower, and high-efficiency diesel generations; and integrate battery storage to stabilize power supply. ADB will continue to work closely with utilities to strengthen energy planning, operations, and financial sustainability.

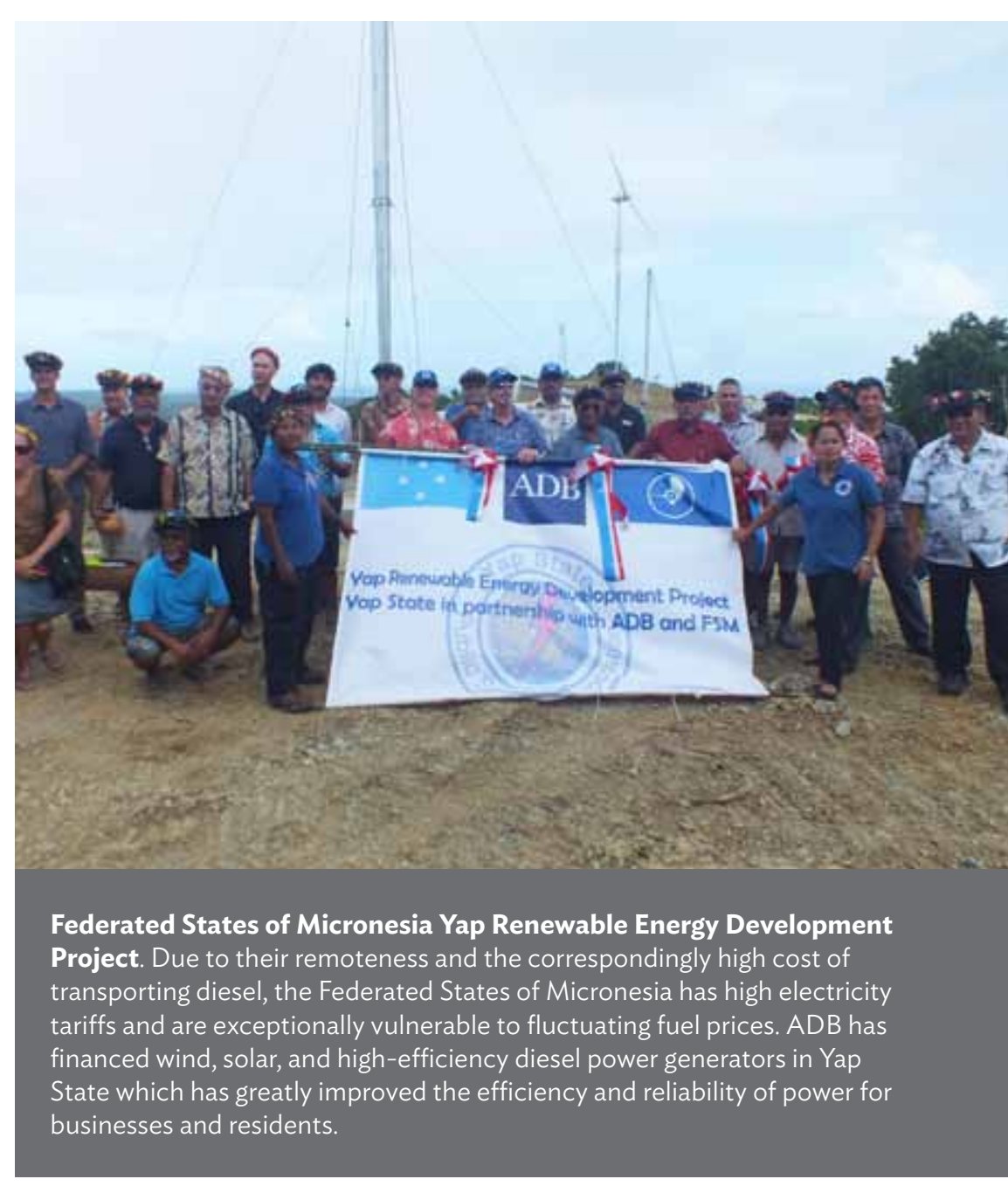


Samoa Renewable Energy Development and Power Sector Rehabilitation Project. Sustainable and reliable electricity is a high priority for Samoa. The project is rehabilitating small hydropower plants near Apia that were damaged by Cyclone Evan in 2012, and constructing new hydropower plants in two rural villages in Upolu and Savaii.

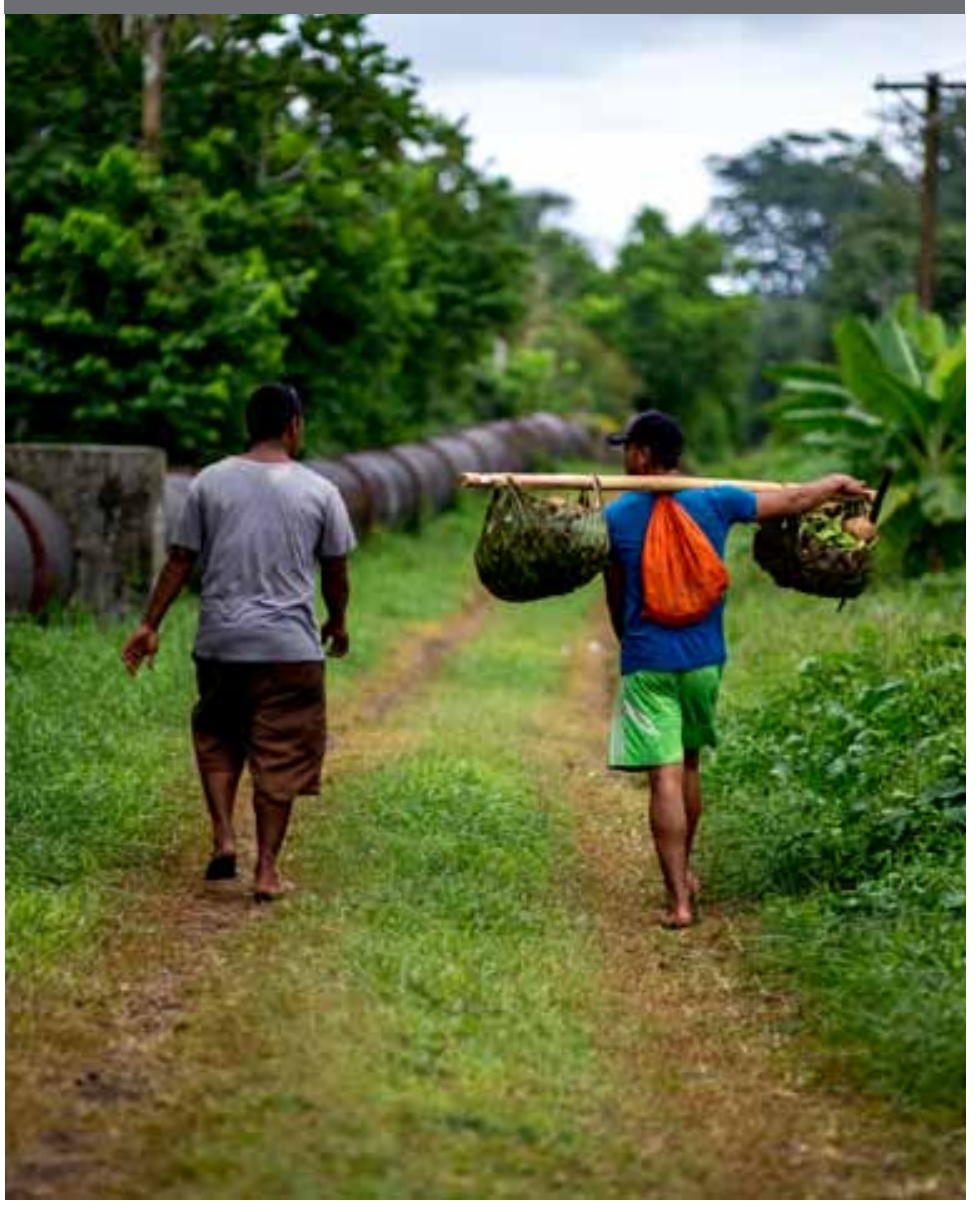

\section{ENERGY OPERATIONS}

AT A GLANCE

At the end of 2018, ADB's portfolio of active loans and grants for energy operations consisted of 14 projects with a total value of $\$ 371$ million. ADB assistance in the Pacific is focusing on expanding renewable energy and bringing electricity to remote and isolated communities.

Total Volume of Active Energy Projects, by Country (\$ million, as of end-2018)

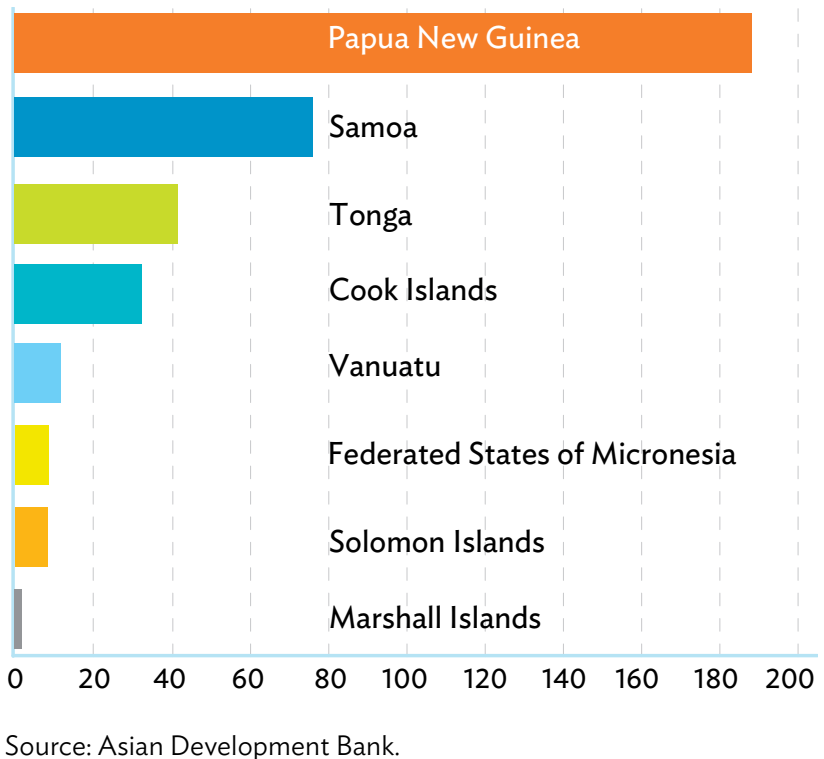

Tonga Outer Islands Renewable Energy Project. By 2020, Tonga aims to source $50 \%$ of its power from renewable resources. The project is constructing solar power systems with a total capacity of 1.32 megawatts on Tonga's nine outer islands, and rehabilitating the existing grid on Vava'u and 'Eua islands.

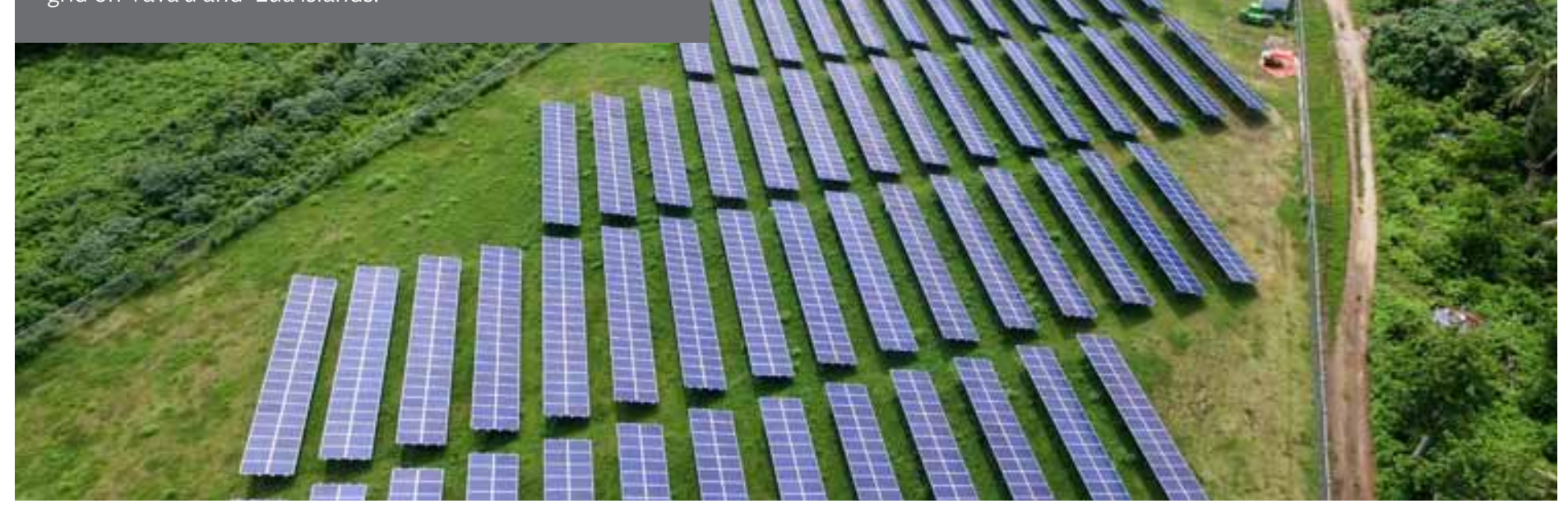




\section{HEALTH}

Communities across the Pacific are experiencing an increase in noncommunicable diseases, challenging health systems with higher costs and managing limited resources to deliver health care. At the same time, there are growing inequalities in access to health services, particularly between urban and rural populations.

ADB has provided support to the health sector in the Pacific for nearly 4 decades. Projects and technical assistance are focusing on improving primary health care in rural areas, by upgrading infrastructure and providing financial management training. ADB has also been investing in digital health information systems to improve evidence-based planning and resource management.

\section{Achieving Results}

ADB's support for Pacific health systems includes building capacities, upgrading key infrastructure, and providing resources to deliver better health outcomes. ADB's assistance has helped PNG revitalize rural health systems in 13 provinces by upgrading more than 115 rural primary health care facilities and training more than 300 rural health workers.

PNG's health system is benefiting from new policies, regulations, institutional arrangements, facilities, and ICT applications to strengthen service delivery and financial management. ADB is also implementing a regional vaccination program in Samoa, Tonga, Tuvalu, and Vanuatu, which will improve overall immunization coverage rates and support greater access to primary health services.

\section{Looking Forward}

ADB's technical assistance in the health sector will continue to support policy reforms, strengthen financial and program management, and train health professionals. ADB will also leverage ongoing developments in ICT across the Pacific to improve the quality and effectiveness of health services.

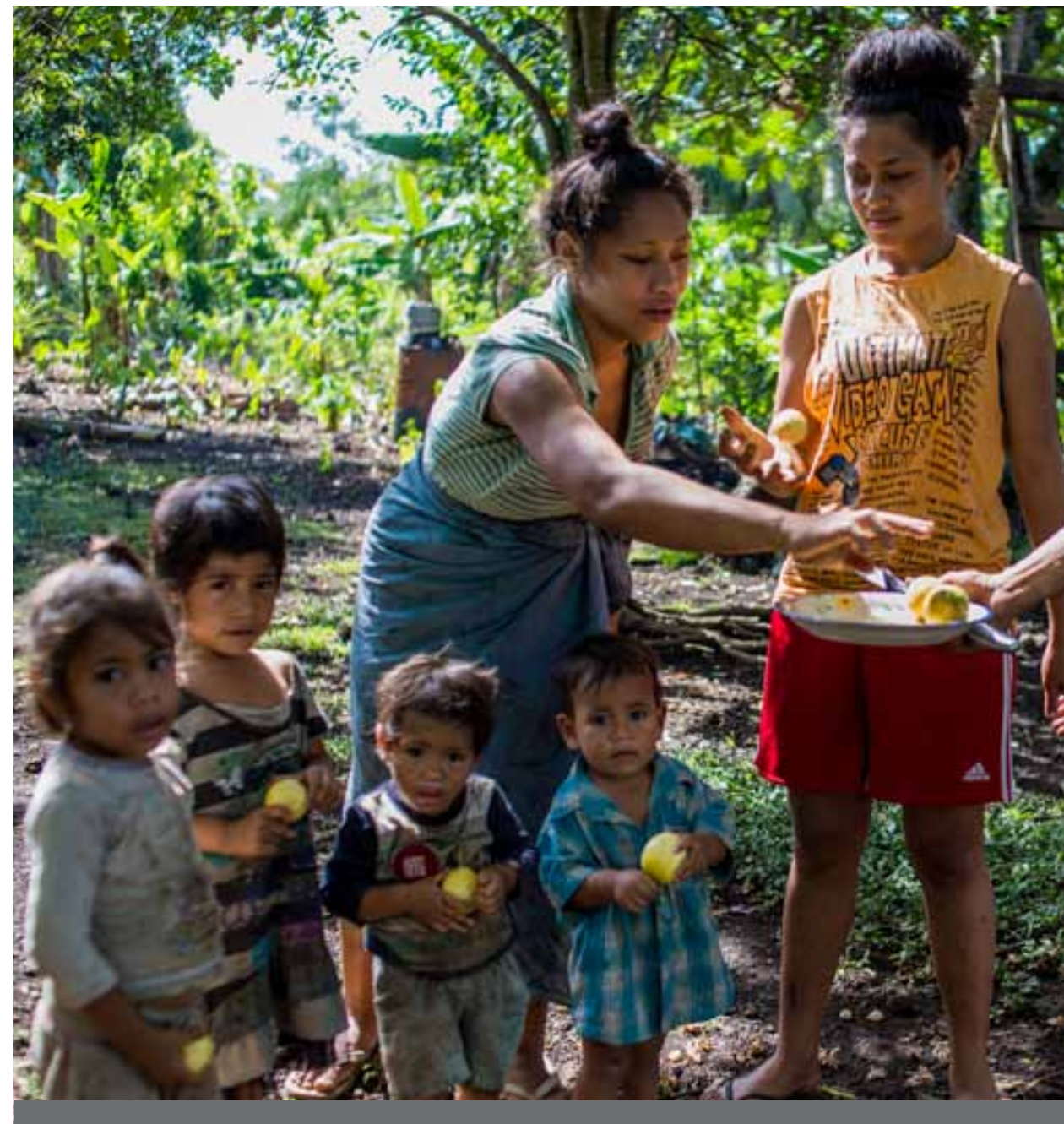

Systems Strengthening for Effective Coverage of New Vaccines in the Pacific Project. This regional initiative will provide immunization coverage for cervical cancer, pneumococcal disease, and rotavirus diarrhea in Samoa, Tonga, Tuvalu, and Vanuatu. The assistance package which supports bulk procurement of vaccines to achieve economies of scale, and is designed to be expanded to other Pacific developing member countries in the future. 


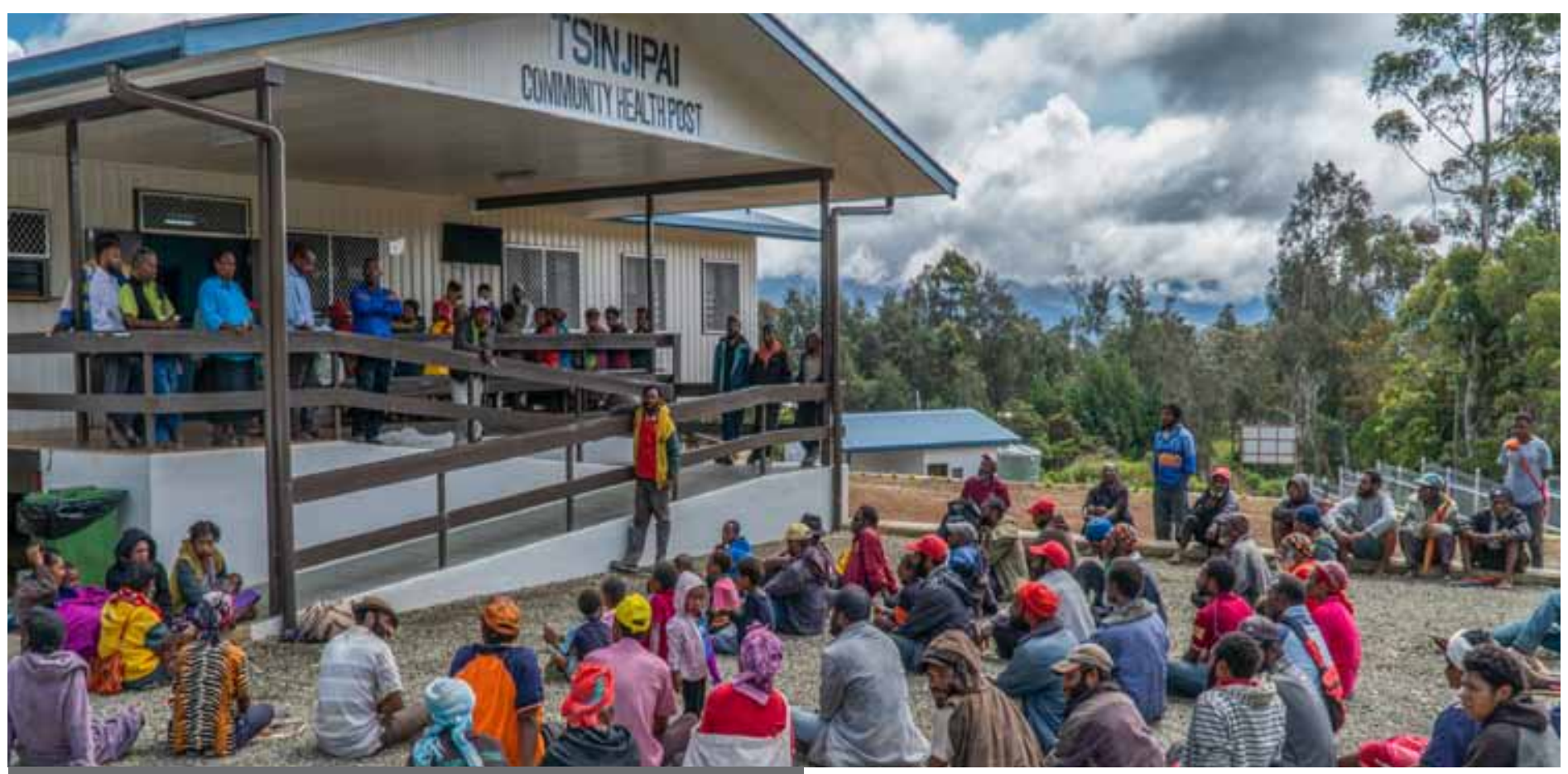

PNG Rural Primary Health Services Delivery Project. The project is supporting rural health systems by (i) strengthening the capacity of health workers with training in obstetrics and reproductive health, (ii) building 39 rural health facilities to make health services more accessible, and (iii) implementing a digital health information system to provide real-time reports for evidence-based planning. The project is contributing to better and more equitable provision of primary health care services in remote communities.

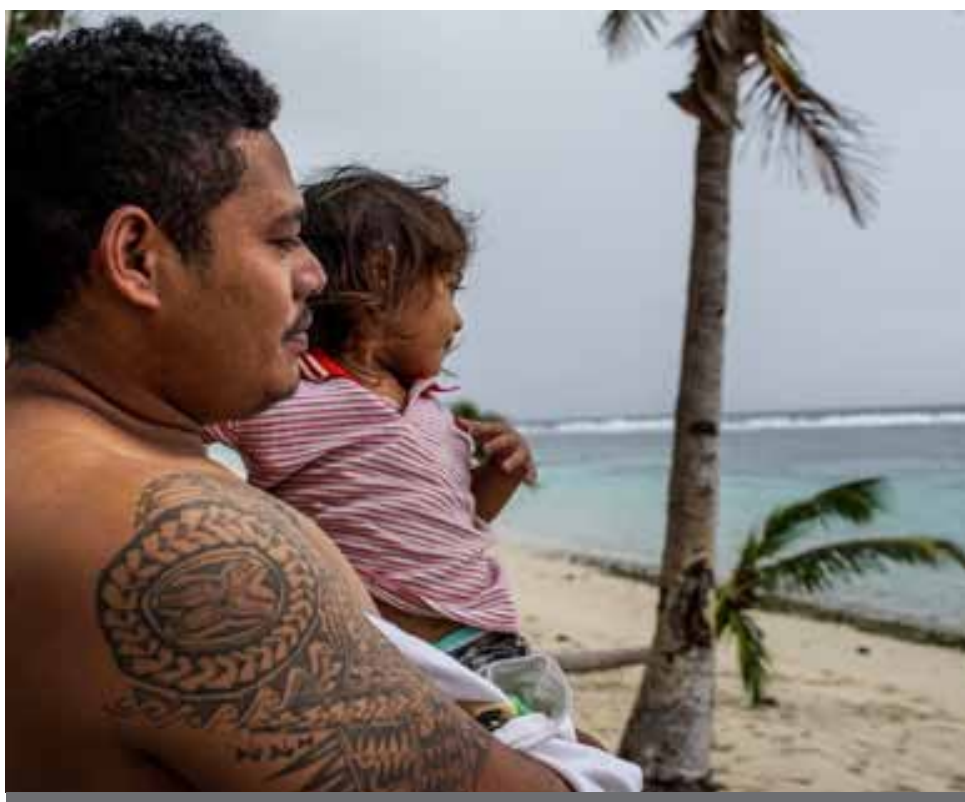

E-Health Component of Samoa Submarine Cable Project. E-health solutions are helping to improve service delivery and reduce the reliance on overseas medical care. Digitizing health information for patients is also helping to improve health planning and identify more cost-effective responses to illnesses.

\section{HEALTH OPERATIONS}

AT A GLANCE

At the end of 2018, ADB's portfolio of active loans and grants for health sector consisted of four projects with a total value of $\$ 296$ million. ADB's assistance is focusing on improving primary health care in rural areas, training health professionals, and expanding vaccination programs.

Total Volume of Active Health Projects, by Country (\$ million, as of end-2018)
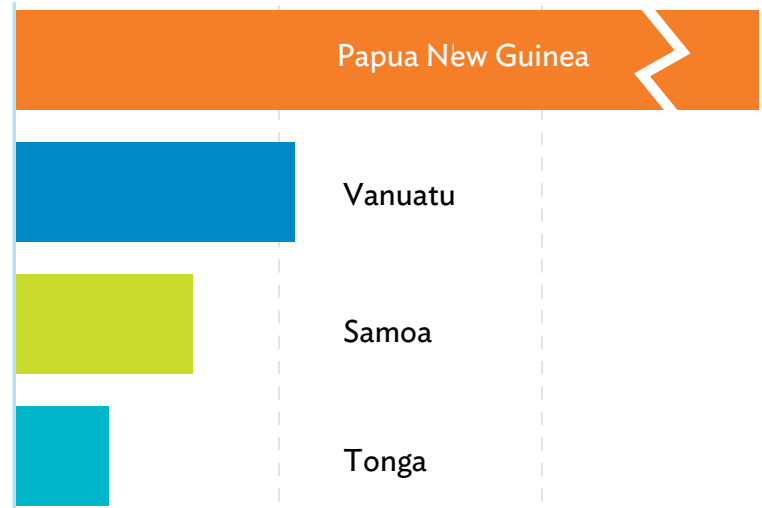

Vanuatu

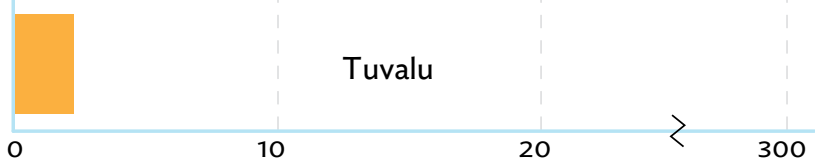

Source: Asian Development Bank. 


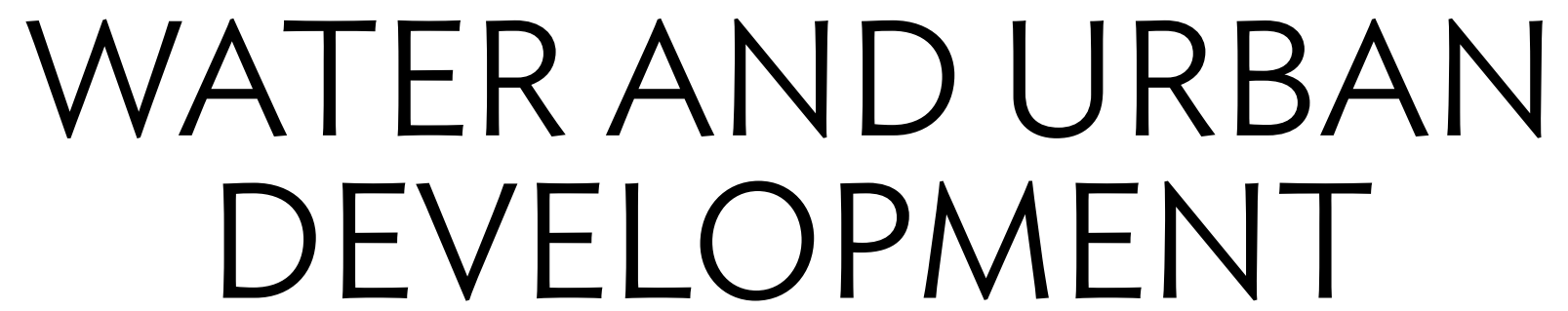

Urban areas in all of ADB's Pacific DMCs are growing rapidly, putting stress on essential services such as water supply and sanitation. The lack of basic services and infrastructure is particularly evident in informal settlements in many towns and cities across the Pacific. Access to safe water, sanitation, and improved solid waste management make cities more livable and directly contribute to better public health outcomes.

ADB is helping governments to plan, design, and construct more resilient urban infrastructure, particularly in the face of climate change and growing exposure to natural hazards. ADB is also strengthening the capacity of water utilities and other key institutions, as well as promoting practitioner networks across countries.

\section{Achieving Results}

From 2008 to 2018, ADB's assistance for urban and water sector projects in the Pacific have helped deliver water supplies to more than 400,000 people; sanitation services to about 100,000 people; and improved drainage for around 100,000 people. Urban road upgrading projects and traffic management schemes have improved travel time and safety conditions for more than 70,000 city dwellers. ADB's urban and water projects are making cities more livable, and supporting better health outcomes across the Pacific.

\section{Looking Forward}

ADB's urban operations in the Pacific will continue to focus on reducing vulnerability to climate change. New projects will involve constructing climate-proof urban infrastructure and strengthening institutional capacities to better plan, regulate, and manage urban assets and services.

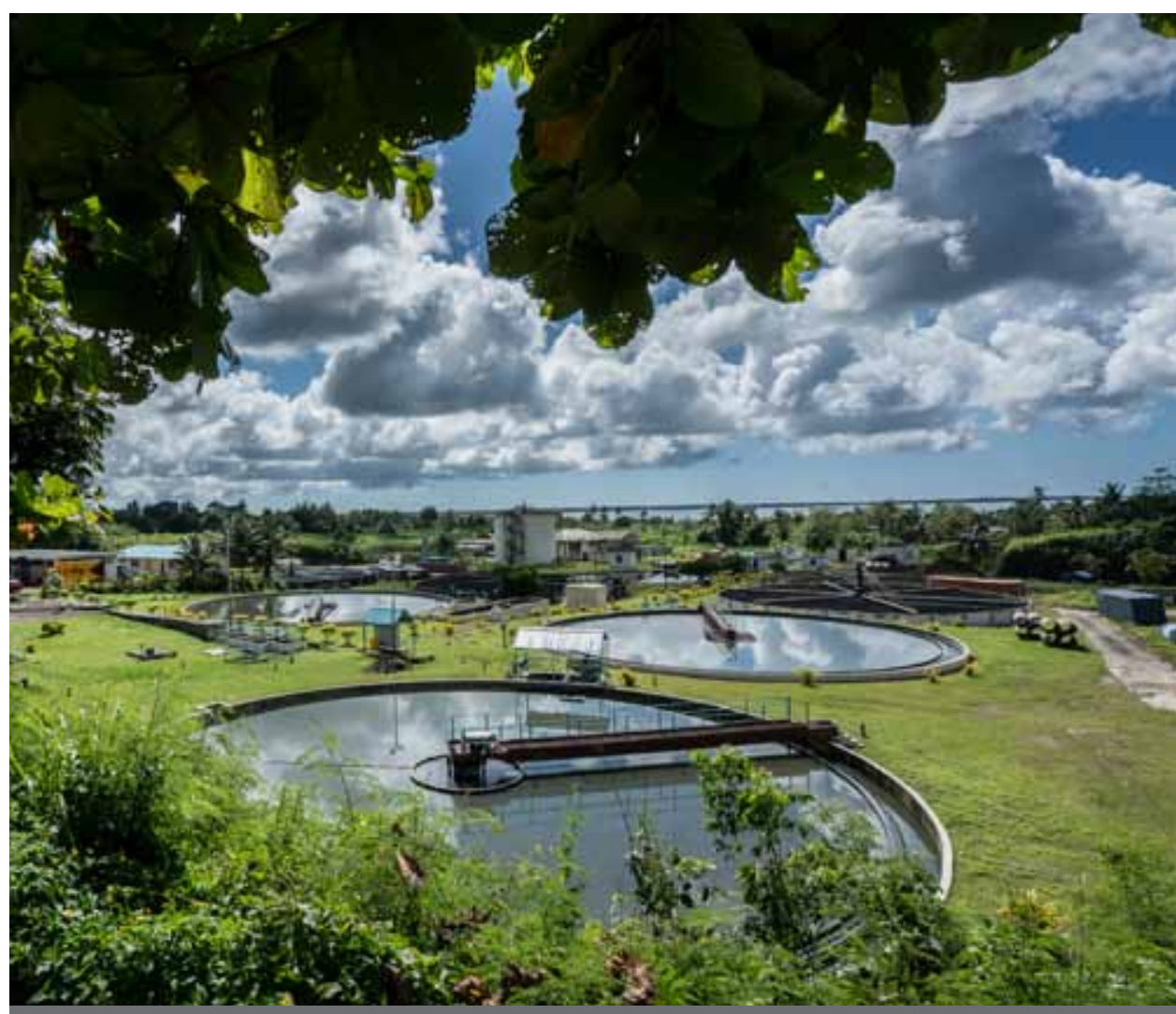

Fiji Urban Water and Wastewater Management Project. The project will expand and renovate infrastructure in the Greater Suva area to increase access to safe water and improve sewerage systems. The project involves constructing a new water intake station on the River Rewa, upgrading the Kinoya wastewater treatment plant, and renovating and expanding water and wastewater infrastructure in the Greater Suva area. The project was the first in the Pacific to receive grant funding from the Green Climate Fund. 


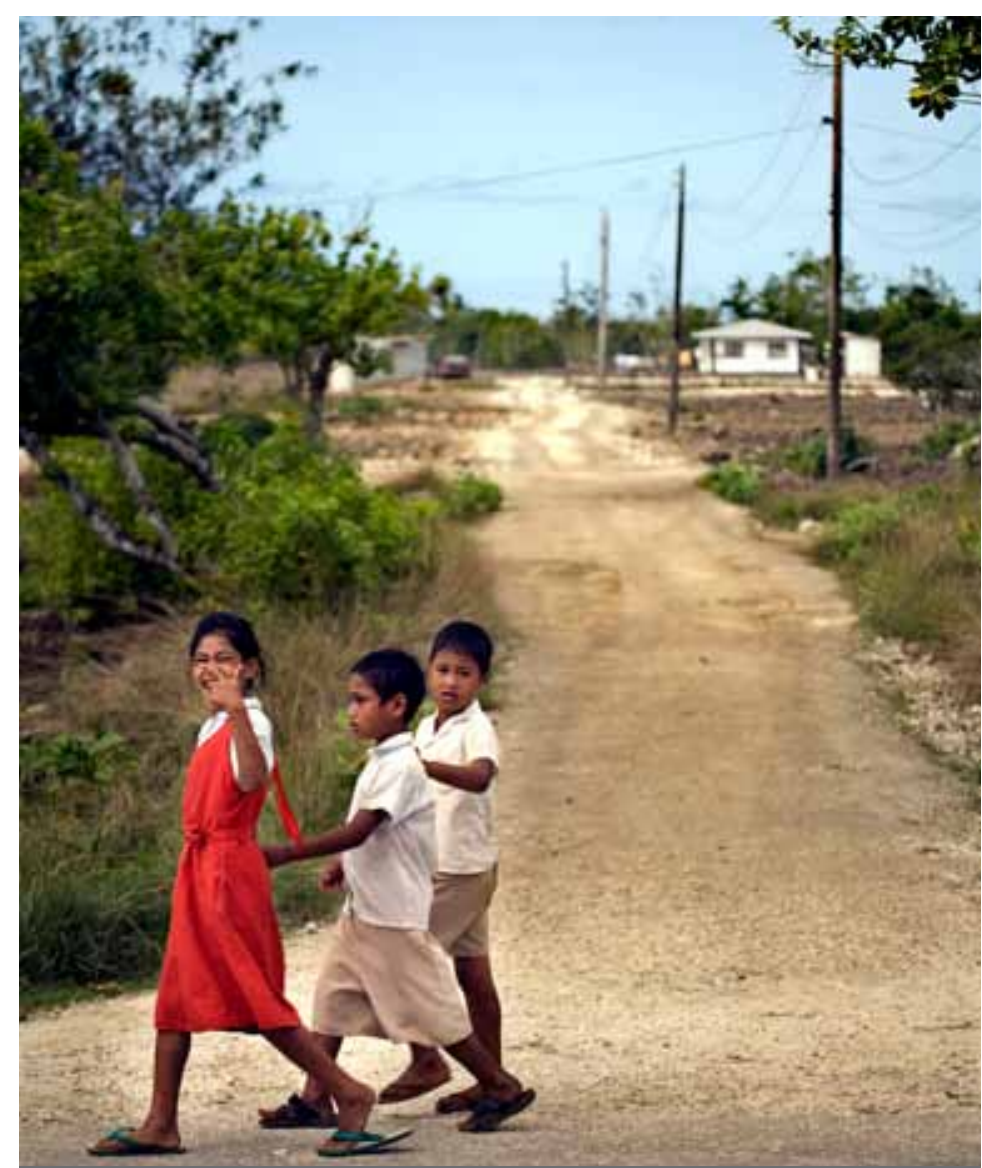

Nuku'alofa Urban Development Sector Project. The project is financing urban infrastructure identified under Tonga's Nuku'alofa Urban Infrastructure Development Plan. The project will contribute to more effective, efficient, and sustainable water supply and solid waste management services in Nuku'alofa; upgrade key municipal infrastructure and establish corresponding maintenance plans; and increase community participation to ensure that impacts are sustainable.

\section{WATER AND URBAN DEVELOPMENT OPERATIONS}

AT A GLANCE

At the end of 2018, ADB's portfolio of active loans and grants for water and urban development consisted of eight projects with a total value of $\$ 182$ million. ADB's assistance is focusing on expanding access to clean water and improving urban sanitation and drainage.

Total Volume of Active Water and Urban Development Projects, by Country ( $\$$ million, as of end-2018)

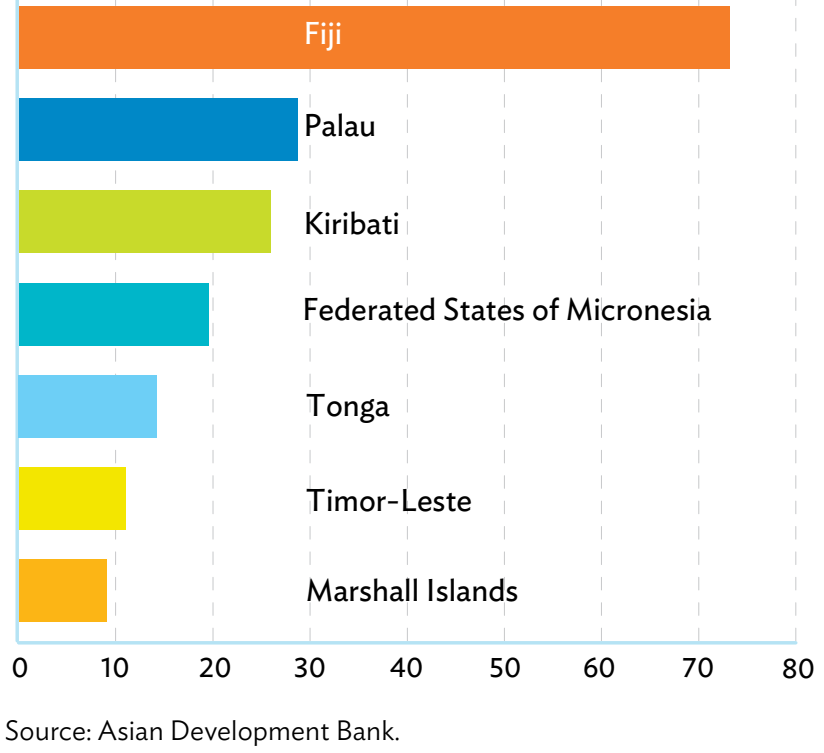

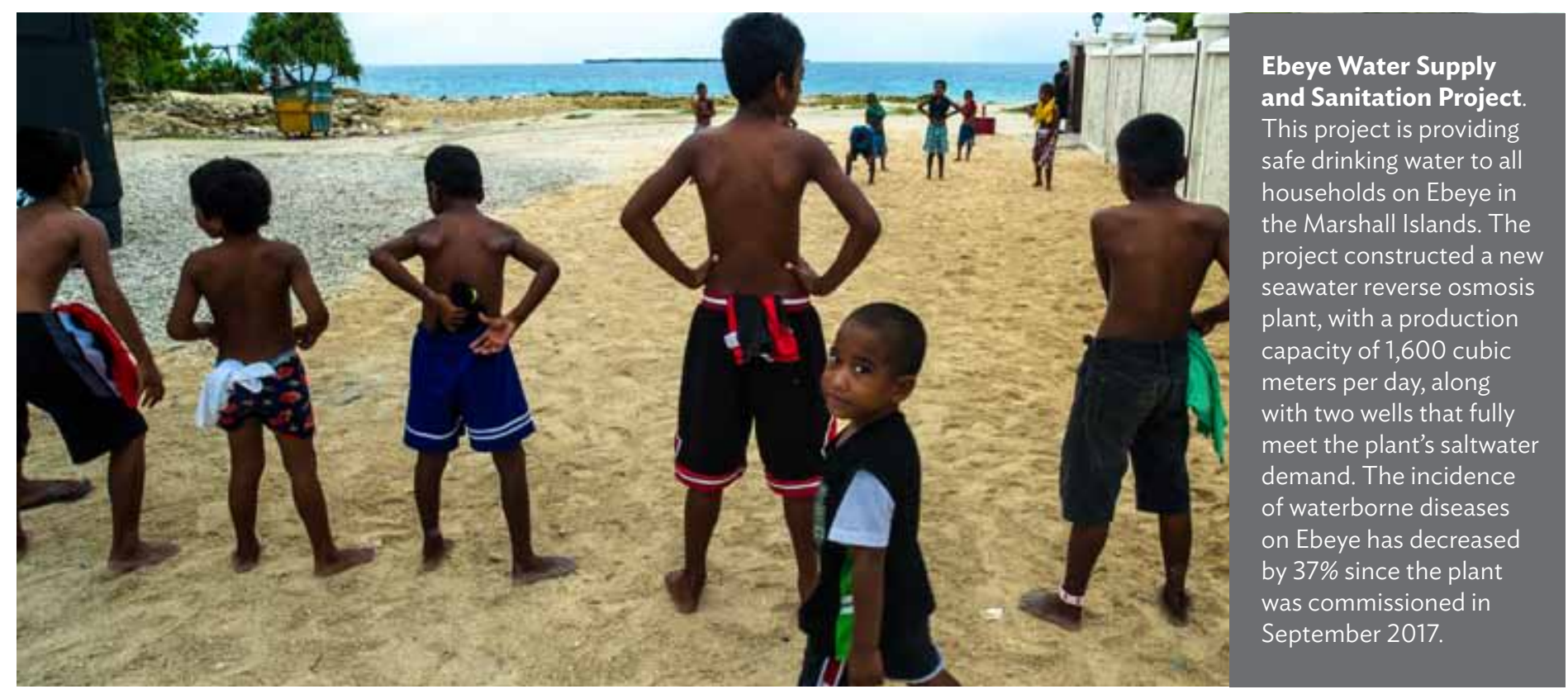




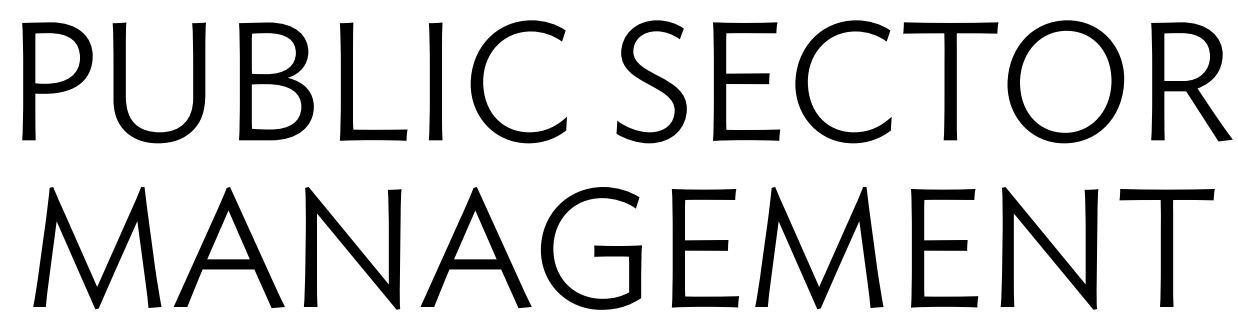

Well-managed institutions, with capable staff, are essential to support economic growth and the sustainable delivery of infrastructure and public services. Given their relatively small economies and limited productive resources, Pacific DMCs rely heavily on external sources of income and imported goods, leaving them vulnerable to commodity price shocks and severe fiscal constraints following disasters.

Sound fiscal planning and sectoral reforms can help attenuate economic damage from external shocks, and strengthen sector performance, service delivery, and financial sustainability. By promoting sound economic management and improving administrative capacities, ADB is helping the Pacific DMCs increase their resilience to external shocks.

ADB's policy-based lending and technical assistance are facilitating macroeconomic and sector reforms across the region. In partnership with multilateral and bilateral agencies, ADB is expanding its support for public financial management, national planning, policy-making, and good governance.

\section{Achieving Results}

ADB's policy-based operations provide quick-disbursing budgetary support alongside policy advice and technical assistance. Policy-based operations have proven to be a crucial instrument for enabling Pacific DMCs to weather and recover from financial crises. These programs have facilitated reforms in key areas, including taxation, public expenditure management, and privatization of state-owned enterprises.

\section{Looking Forward}

In order to deliver sustained progress in poverty reduction, ADB's public sector management initiatives will continue to provide policy makers with advice and capacity building to enable them to design and manage reforms. ADB is facilitating Pacific DMCs adopt improved policies, regulatory frameworks, and fiscal measures to mitigate, and recover from economic shocks.

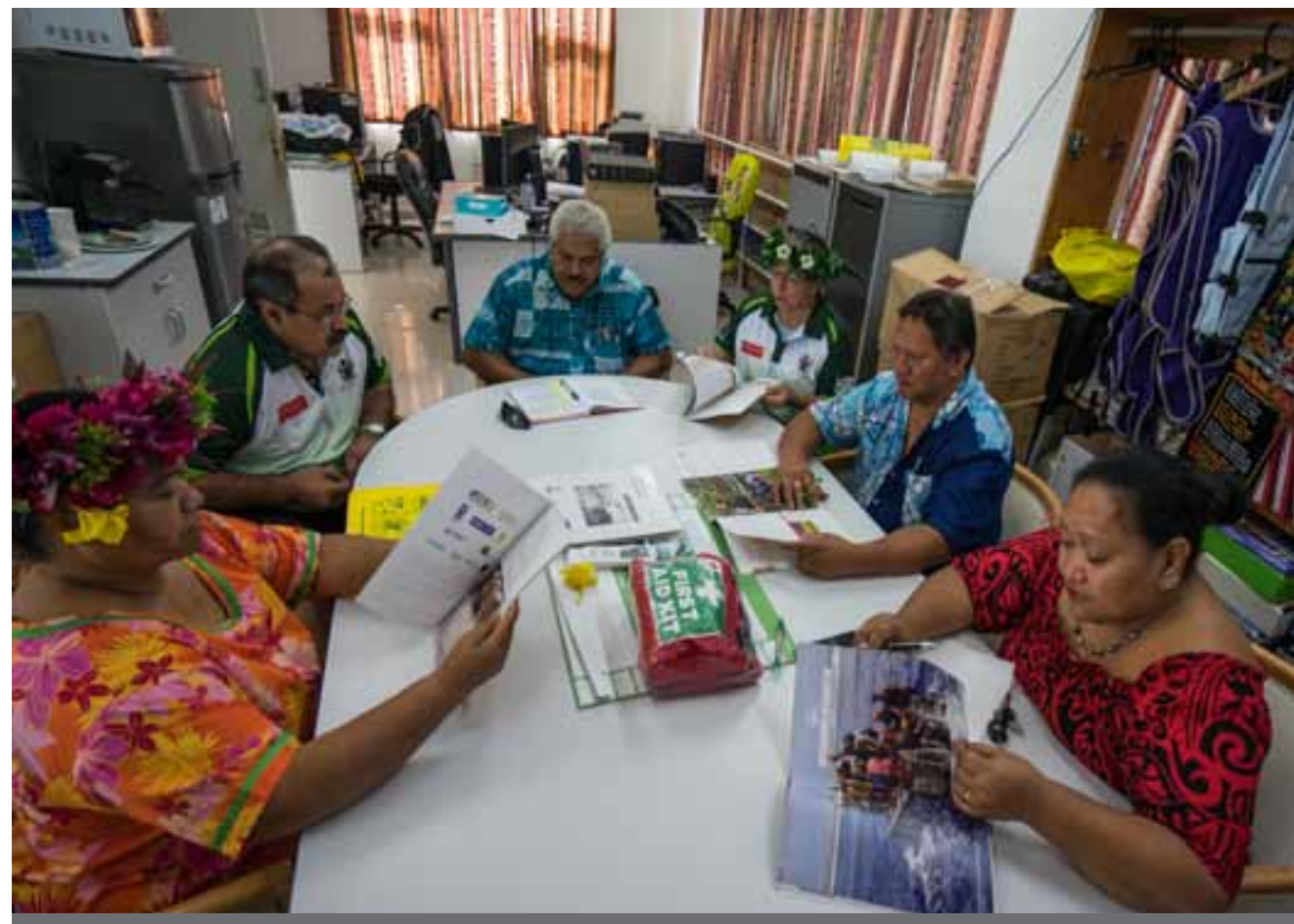

Cook Islands Disaster Resilience Program. In 2016, ADB introduced its first postdisaster contingent credit line in the Cook Islands, thereby reducing fiscal and economic exposure to the effects of natural hazards. The $\$ 10$ million contingent credit line provides immediate liquidity in the event of a natural disaster. ADB has since expanded coverage in the Pacific region by launching similar programs in Palau, Samoa, Tonga, and Tuvalu. 


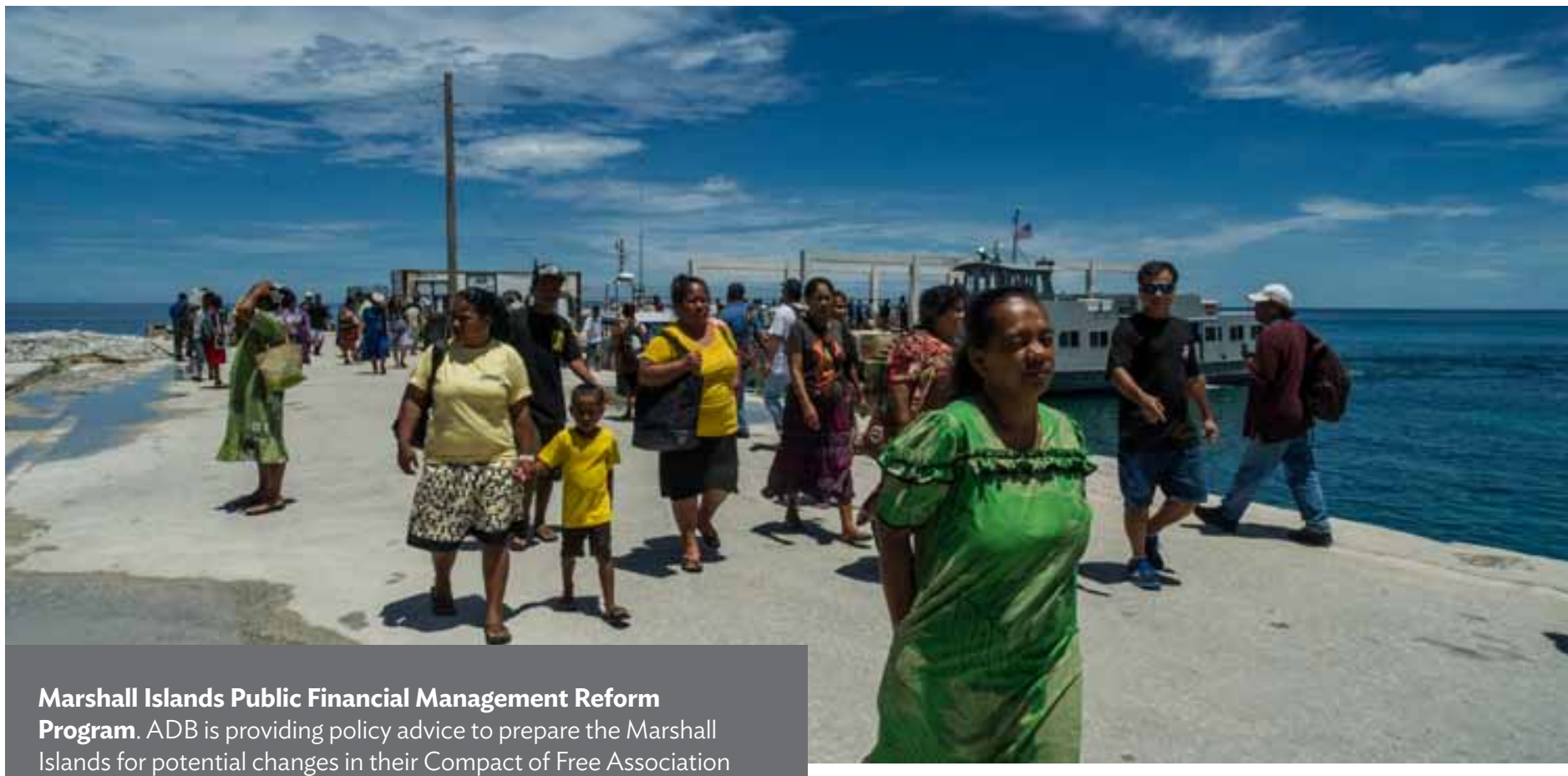

Islands for potential changes in their Compact of Free Association with the United States. The project is looking at ways to reduce fiscal burdens associated with supporting state-owned enterprises, and to strengthen capacities to implement public financial management reforms.

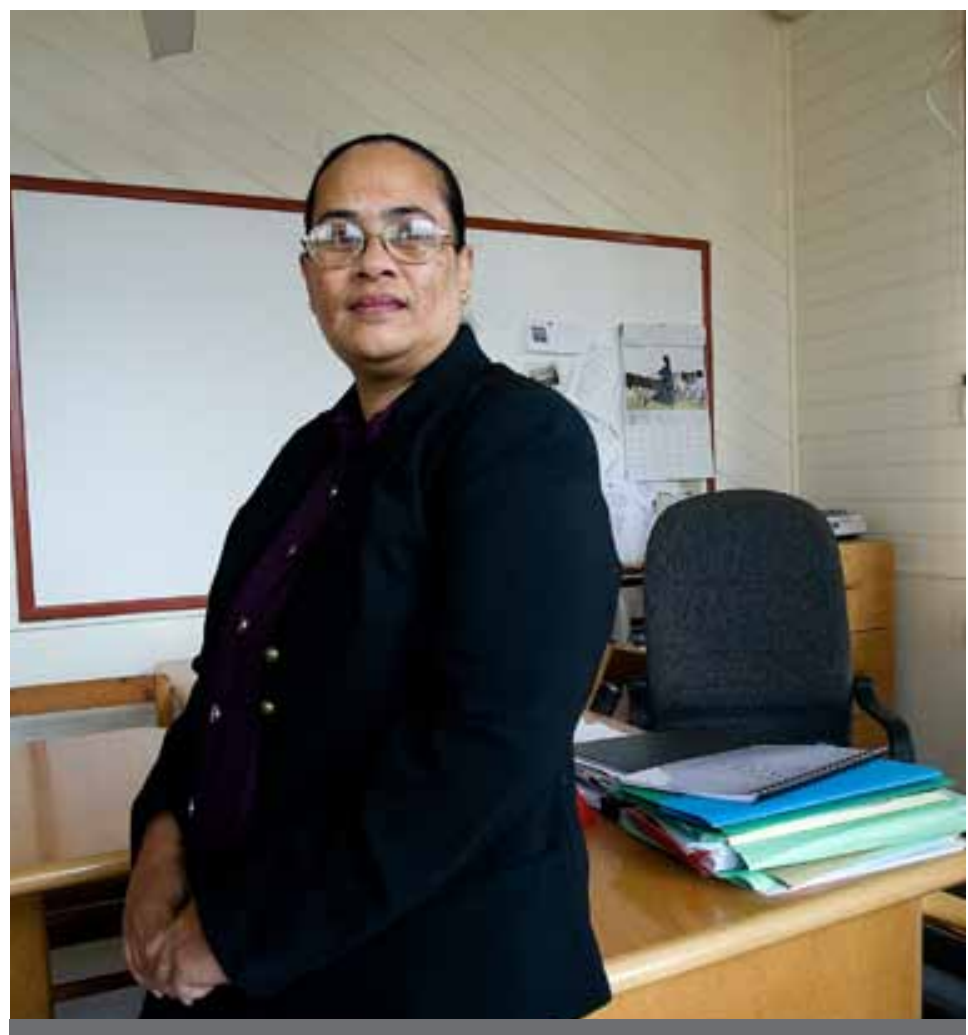

Tonga Public Sector Management Reform Programs.

A series of policy-based programs are helping Tonga to improve fiscal resilience, enhance public expenditure management, and create an enabling environment for the private sector to drive economic growth.

\section{PUBLIC SECTOR MANAGEMENT OPERATIONS}

AT A GLANCE

At the end of 2018, ADB's portfolio of active loans and grants for public sector management consisted of 11 initiatives with a total value of $\$ 84$ million. ADB's assistance is supporting revenue generation and improved public expenditure management.

Total Volume of Active Public Sector Management Projects, by Country ( $\$$ million, as of end-2018)

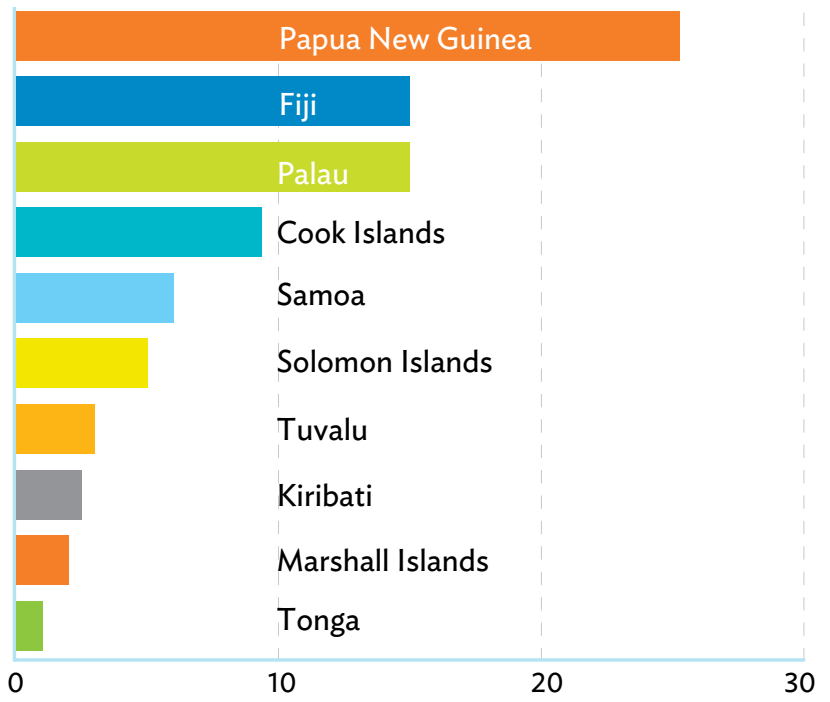

Source: Asian Development Bank. 


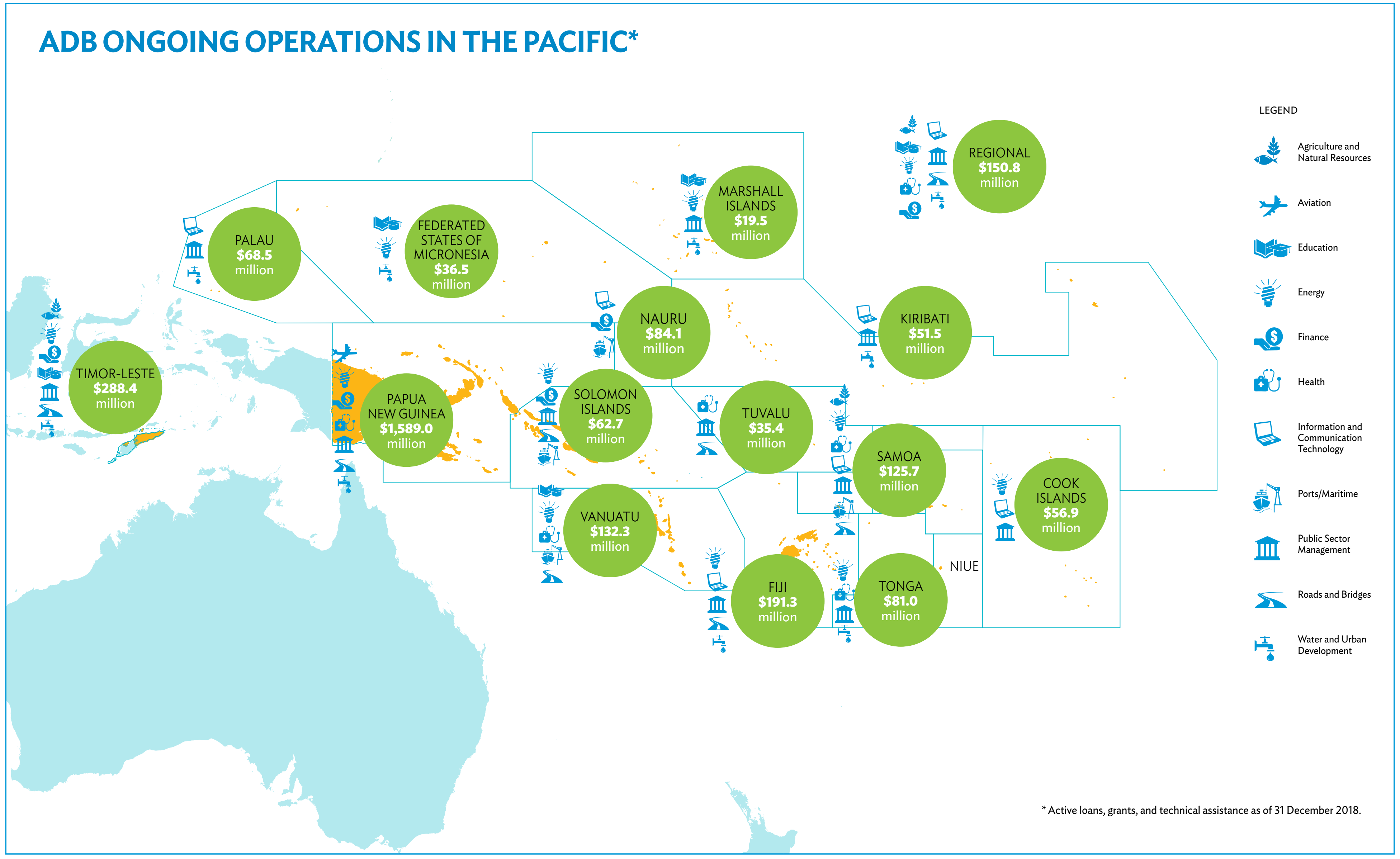




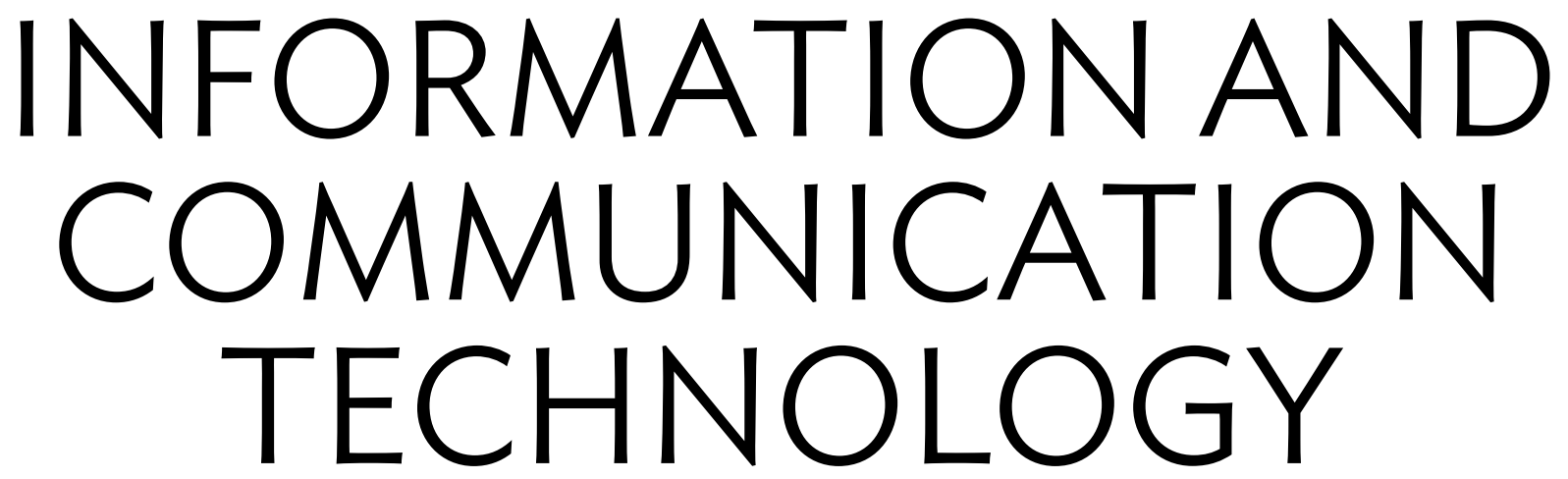

Access to affordable, high-speed internet service is essential for businesses and communities in the Pacific to overcome the challenges associated with their geographic isolation. $A D B$ is financing submarine fiber-optic cables, and exploring applications for digital education, health, and governance. Investments are connecting people to the internet for the first time and delivering major improvements in services. New and faster connections are also creating job opportunities, facilitating financial transactions, and helping to share knowledge and information with remote communities.

\section{Achieving Results}

ADB's ICT projects have laid over $5,000 \mathrm{~km}$ of fiber-optic submarine cables across the Pacific. The result is faster data transfer and lower internet costs for individuals and organizations. In Palau, for example, the cost of data transfer has dropped by more than $75 \%$ after the cable became operational. In Tonga, the submarine cable project reduced internet costs by a similar factor, and more than doubled connection speeds. Overall, ADB expects its ICT projects to cut internet costs by more than half for over 400,000 people in the Cook Islands, Kiribati, the Federated States of Micronesia, Nauru, Palau, and Samoa.

\section{Looking Forward}

ADB will continue to help communities harness the benefits of better ICT by leveraging practical applications in digital education, finance, health, and governance. For example, many Pacific utilities are now monitoring service use and accepting digital payments. By the end of 2020, almost all Pacific countries will have high-speed broadband internet, thereby reducing costs and creating new opportunities through improved connectivity.

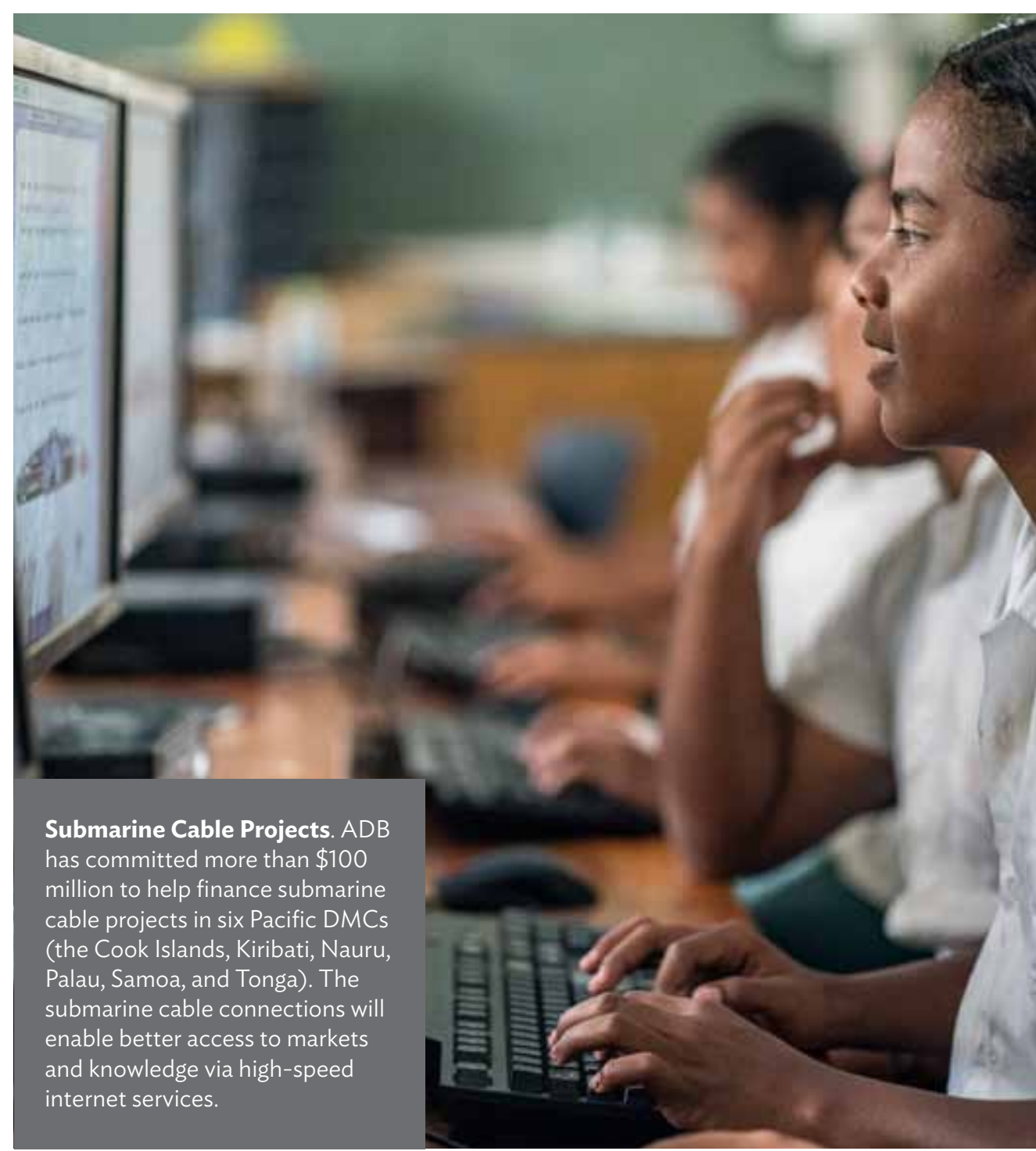


E-Governance in the Cook Islands. ADB's technical assistance is helping the Government of the Cook Islands to review its existing ICT infrastructure and institutional capacities to support e-governance initiatives, including a new ICT strategy and development plan.

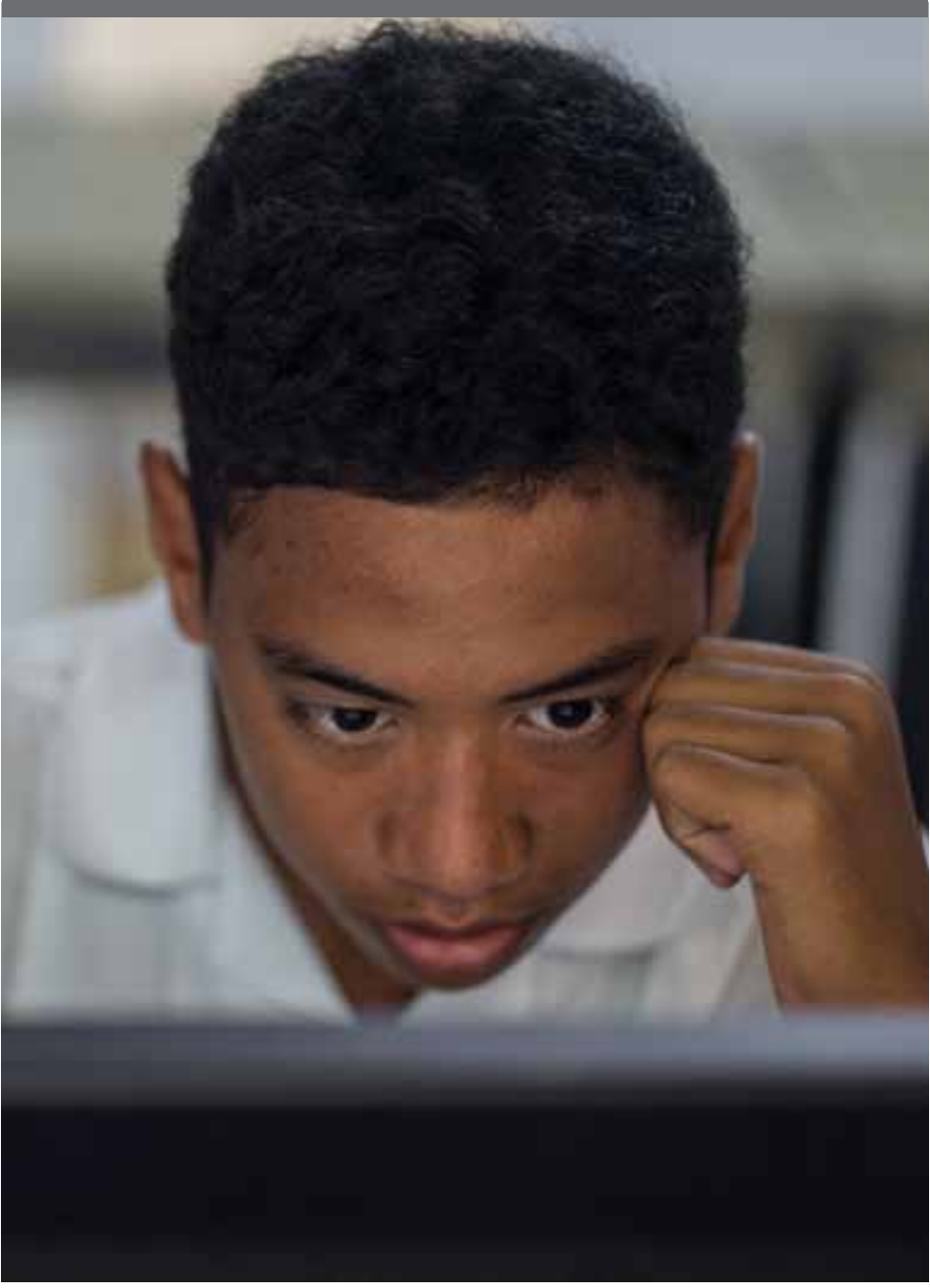

\section{ICT OPERATIONS \\ AT A GLANCE}

At the end of 2018, ADB's portfolio of active loans and grants for ICT consisted of five projects with a total value of $\$ 101$ million. ADB's assistance has focused on the introduction of submarine fiber-optic cables that give local communities and businesses better access to the internet, create new job and market opportunities, and facilitate service delivery.

Total Volume of Active ICT Projects, by Country (\$ million, as of end-2018)

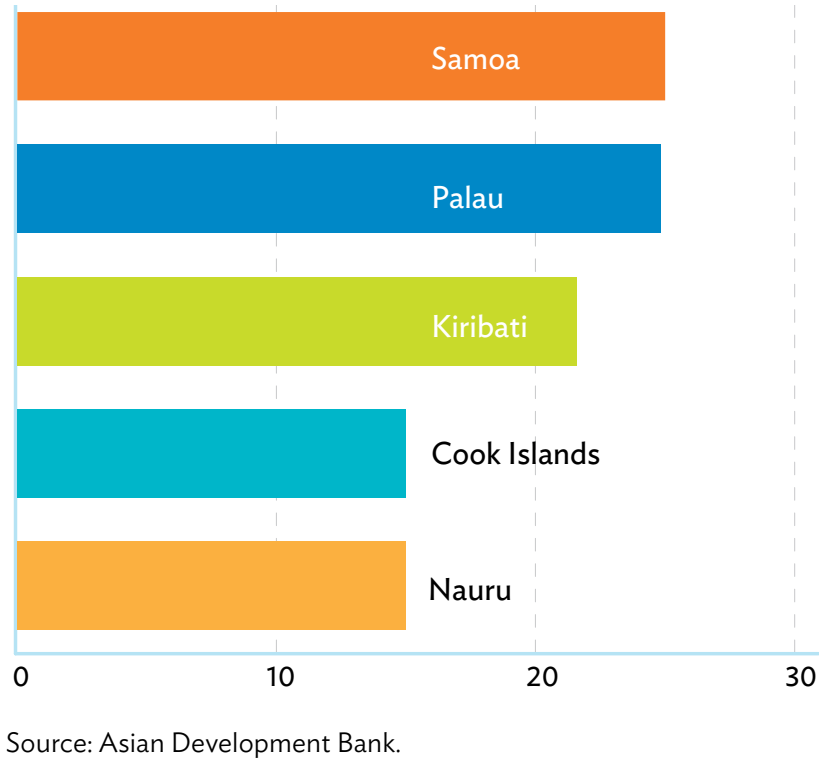

Prepaid Meters Improve Revenue Collection. ADB is helping finance the installation of prepaid digital water and electricity meters and corresponding monitoring software. The equipment and software are enabling utilities across the Pacific to conserve resources, improve revenue collection, and enhance their commercial viability and economic performance.

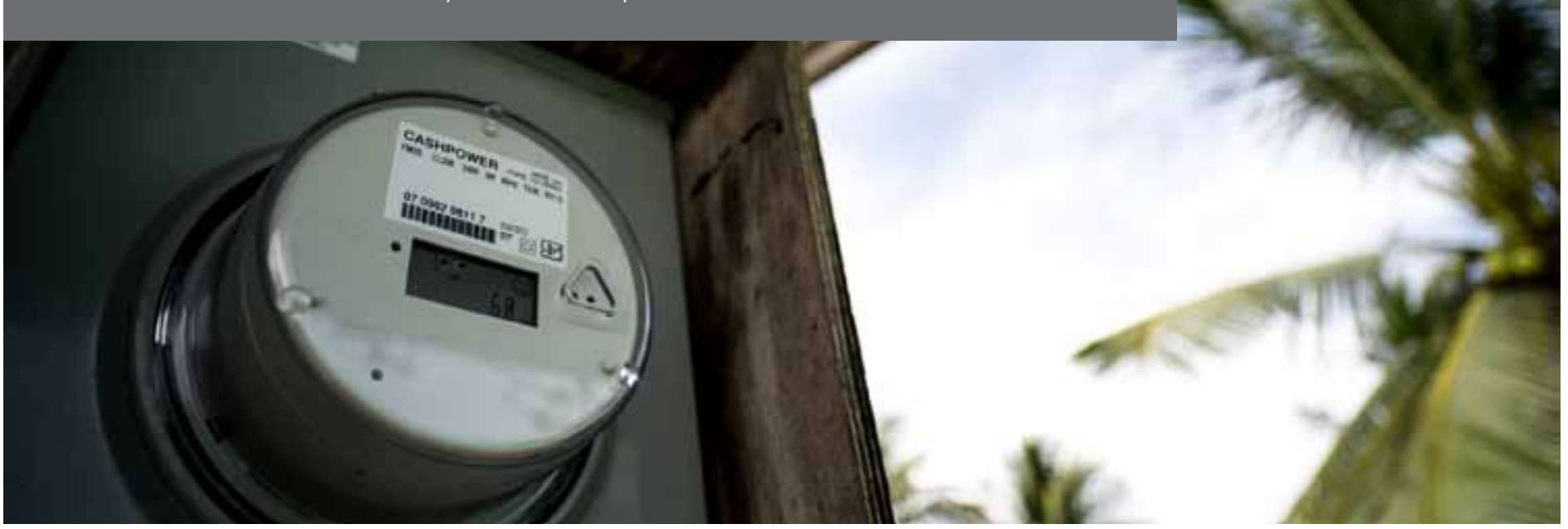




\section{EDUCATION}

Human capacity development is fundamental to improving opportunities and laying the foundation for a better, stronger economy. ADB is supporting education programs across the Pacific to build knowledge and skills that respond to labor market demands. Improved ICT infrastructure is creating new ways to deliver more efficient and effective education services, especially to remote areas.

\section{Achieving Results}

ADB is supporting a diverse range of initiatives to strengthen education services in the Pacific, including training nearly 2,000 teachers for new quality or competency standards. The development of new ICTenhanced campuses at the University of the South Pacific in Kiribati and in Solomon Islands will provide nearly 6,000 students with improved access to higher education. Initiatives to strengthen literacy and numeracy in the North Pacific are benefiting more than 5,000 primary school students. In Timor-Leste, ADB helped provide post-secondary skills training to more than 3,000 students.

\section{Looking Forward}

Small and isolated economies in the Pacific require innovative strategies to deliver high-quality education outcomes. ADB is supporting the Pacific Regional Education Framework, which allows all Pacific countries to access services from participating regional organizations to improve the quality of education. ADB is leveraging new ICT applications, such as digital learning resources and data management systems, for more costeffective education services across the Pacific. In close cooperation with development partners, ADB will expand its support in the education sector to improve opportunities for future generations of Pacific islanders.

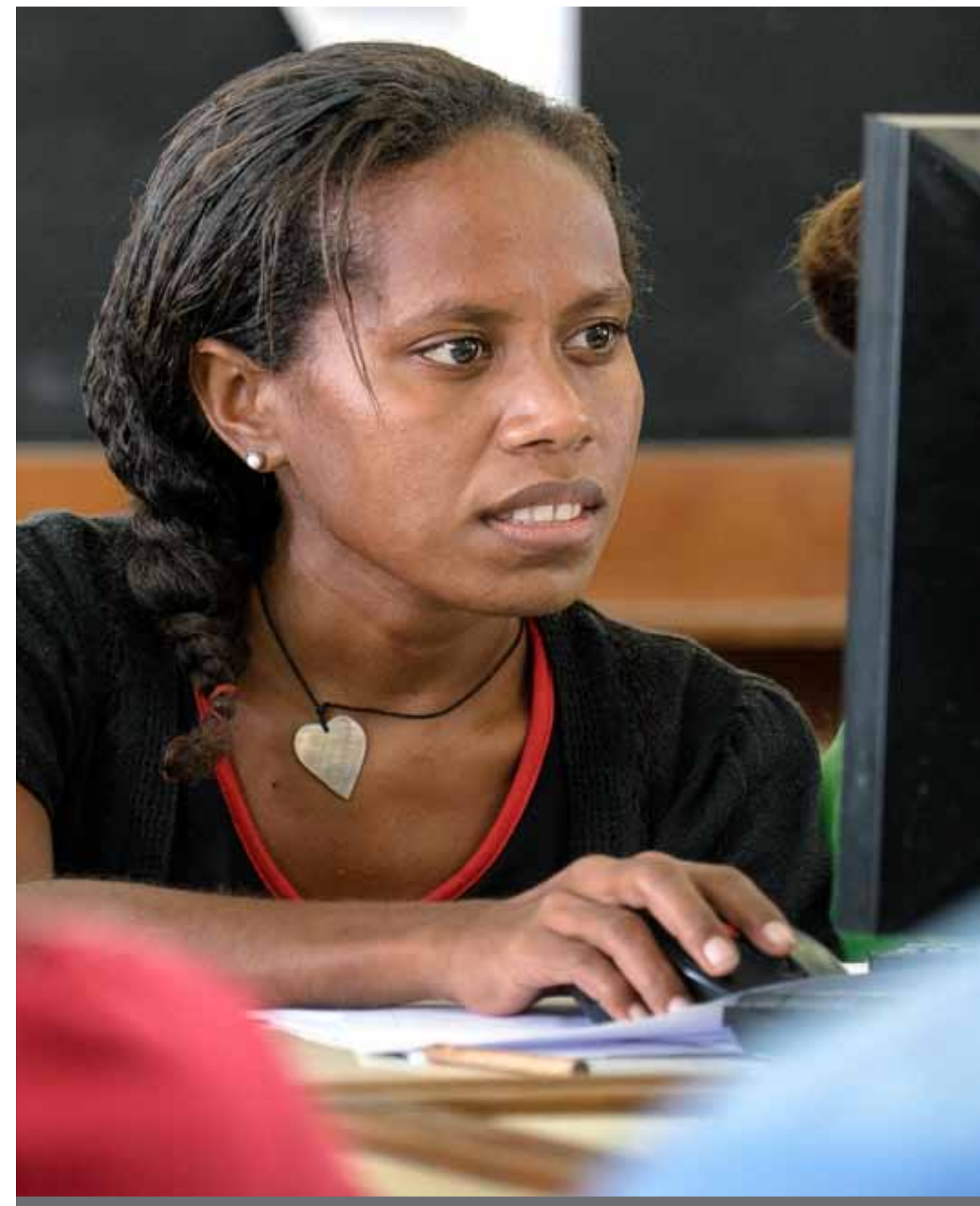

Regional Platform for E-learning (Open, Distance, and Flexible Learning). ADB is leveraging ICT to deliver quality digital teaching and learning resources across the region, beginning with a pilot in Fiji, and in close coordination with the Government of New Zealand and the University of the South Pacific. 
Improving the Quality of Basic Education in the North Pacific Project. ADB is providing comprehensive support for basic education systems, including teacher training, to improve learning outcomes in the Marshall Islands and the Federated States of Micronesia.

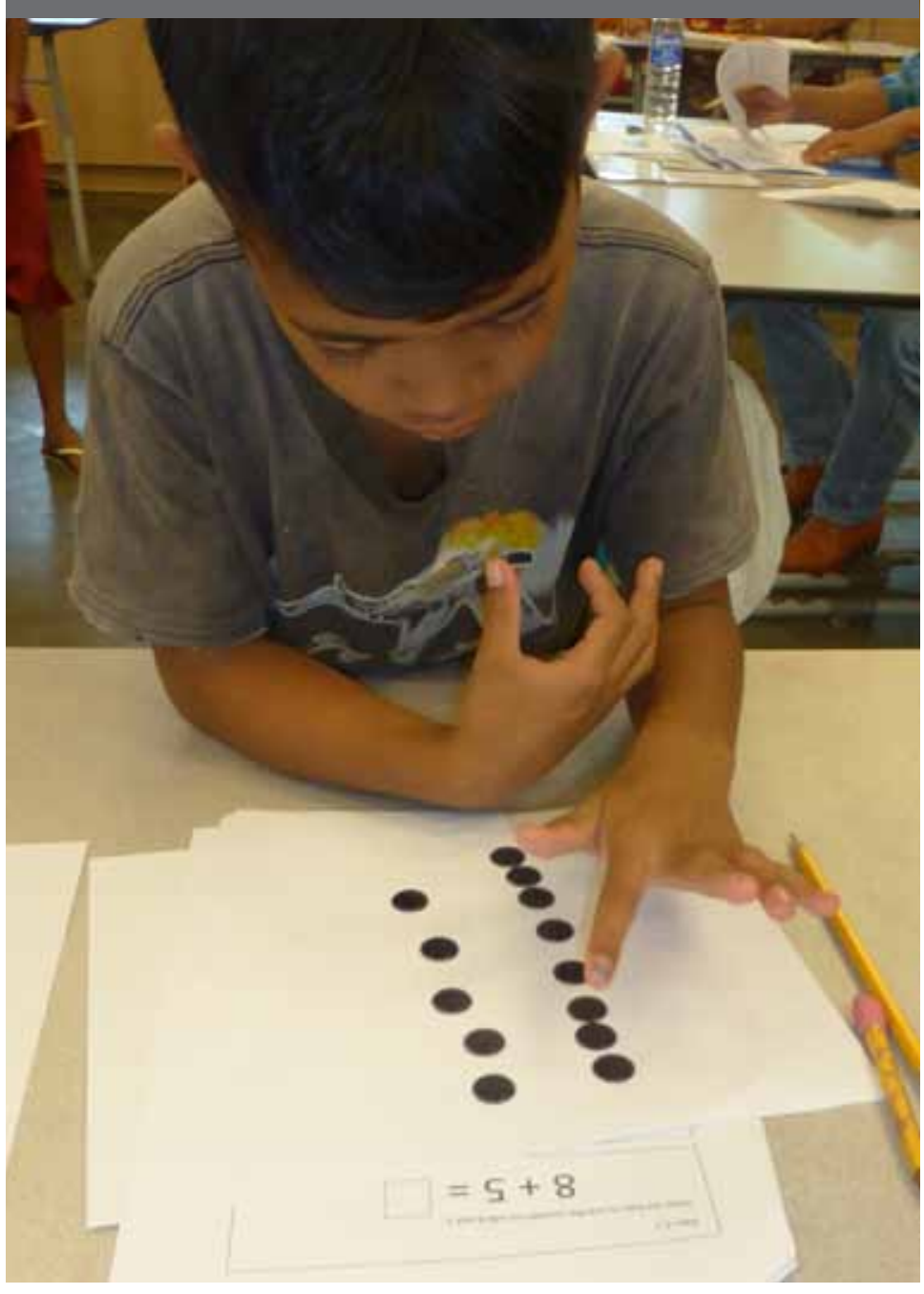
EDUCATION OPERATIONS
AT A GLANCE
At the end of 2018, ADB's portfolio of active loans and grants for education sector consisted of five projects with a total value of $\$ 49$ million. ADB's assistance covered many different types of education-basic education, skills development, and higher education- in response to varying local needs. ICT is helping to improve the reach and effectiveness of education services.

Total Volume of Active Education Projects, by Country (\$ million, as of end-2018)

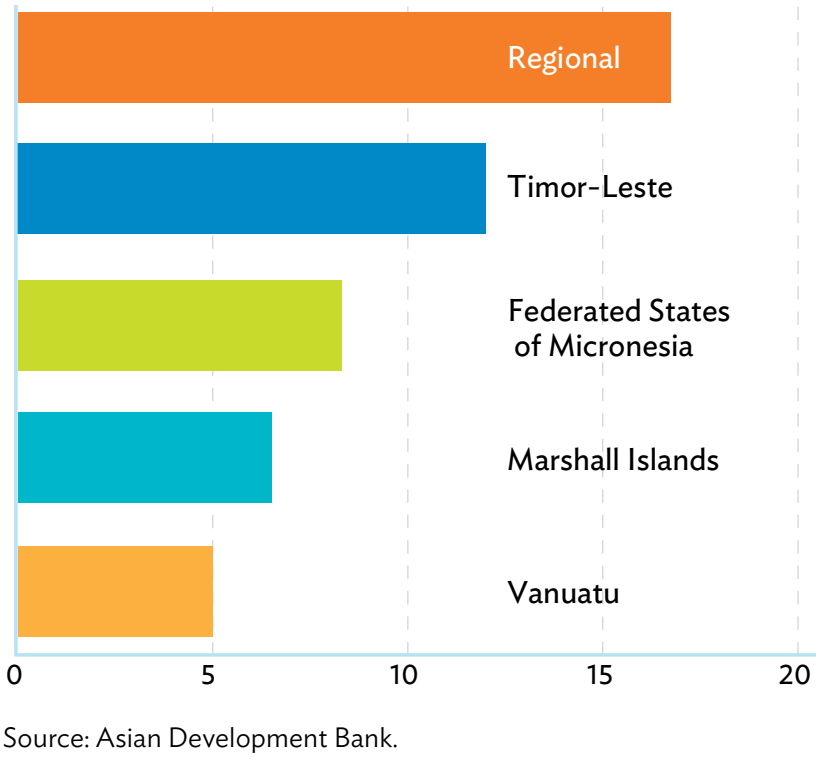

Timor-Leste Mid-Level Skills Training Project. ADB's assistance has provided more than 3,000 students with accredited training in construction and automotive skills through five domestic training centers, helping match labor market demand with capable workers.

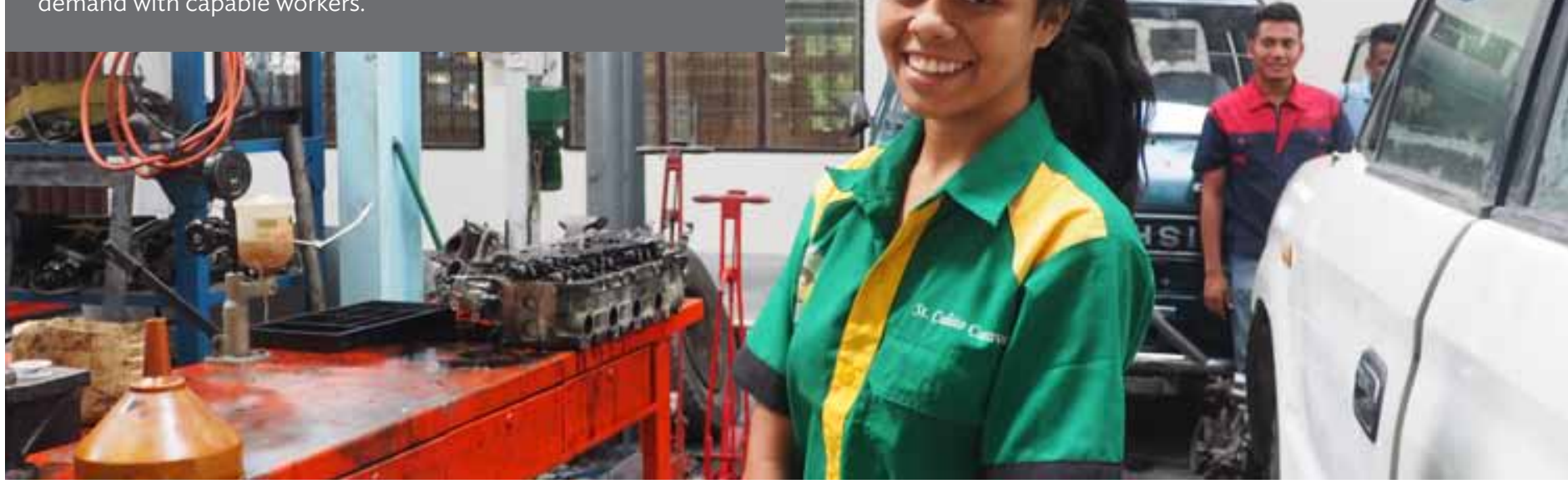




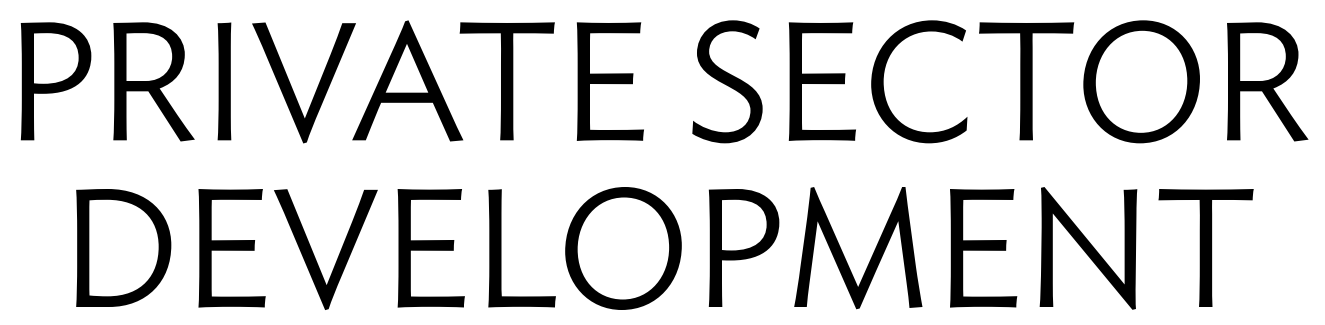

Sustaining economic growth and reducing poverty requires a dynamic and efficient private sector. ADB is financing selected private sector investments, and leveraging technical assistance and sovereign investments, to enable Pacific DMCs to improve their business environments and attract new international investment.

In 2007, ADB and the governments of Australia and New Zealand launched the Pacific Private Sector Development Initiative (PSDI), a flagship regional program aimed at creating an enabling environment for business and investment across the Pacific. PSDI is supporting business law reforms, public-private partnerships, state-owned enterprise (SOE) reforms, the economic empowerment of women, stronger consumer protection and competition policies, and improved access to finance for business and households.

\section{Achieving Results}

PSDI's work in the region has been transformative. Since its establishment, it has supported reforms and investments resulting in (i) the provision of 60,000 new loans to individuals and smalland medium-sized enterprises in seven Pacific DMCs by allowing borrowers to use security other than land; (ii) the transformation of microfinance institutions in PNG and Timor-Leste into commercial banks; (iii) the reform of company laws and establishment of online business registries in five Pacific DMCs; (iv) the privatization of four SOEs, and completion of two public-private partnership transactions; ( $v$ ) improved profitability of SOEs in Fiji, the Marshall Islands, Samoa, Solomon Islands, and Tonga; and (vi) greater economic empowerment of women, including an increased number of women directors and shareholders in both public and private enterprises.

ADB's transactional advisory services are also helping to increase private sector participation in services delivery. In Timor-Leste, for example, $A D B$ is helping attract private sector involvement in solid waste management in Dili; in PNG, ADB is helping engage the private sector to finance, construct, and manage a new passenger terminal for Jacksons International Airport in Port Moresby; and in Tonga, ADB is helping attract private sector financing for a 6-megawatt solar generation plant.

\section{Looking Forward}

ADB will continue to provide advice and technical assistance to support business-friendly policies and legal reforms as well as transaction advisory services to help Pacific DMCs mobilize private sector investment structure viable public-private partnerships.

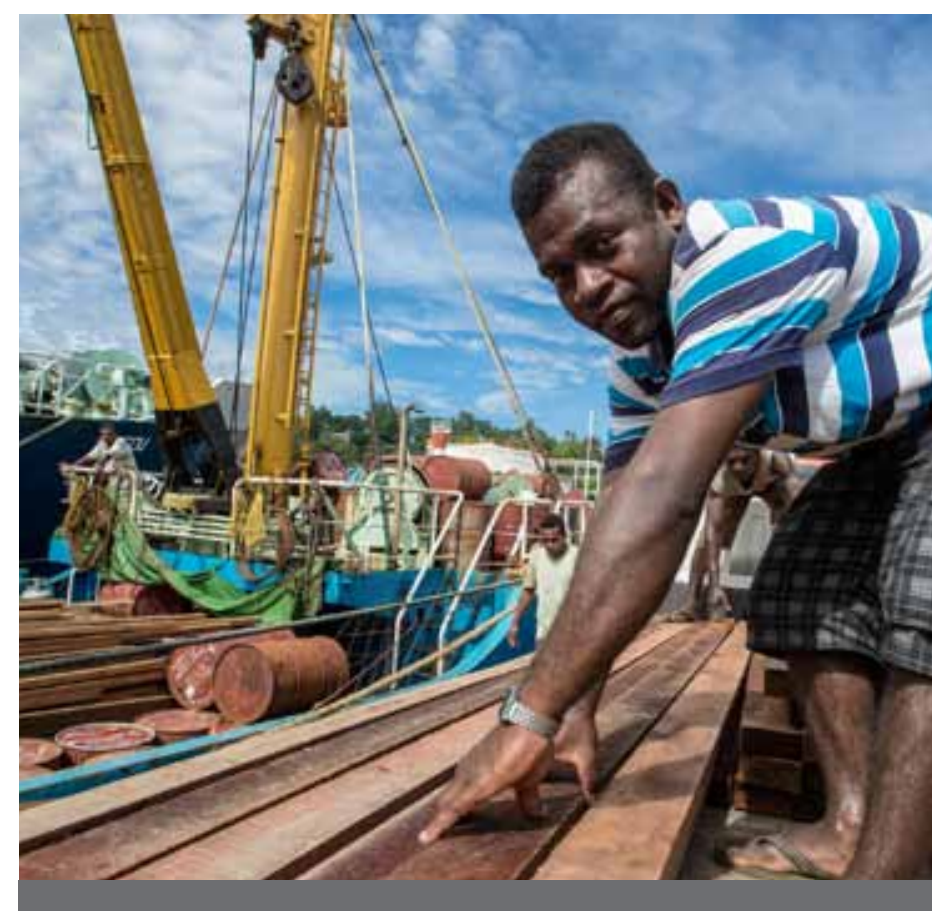

Secured Transactions Law and Registry Reform. The Pacific Private Sector Development Initiative has supported the successful implementation of secured transactions law and registry reforms in seven countries. The new laws enable borrowers to provide lenders with security interests using various forms of movable property, including equipment, inventory, accounts receivable, contracts, crops, livestock, and shares. Over 60,000 new secured loans have now been provided. In Tonga, farmers are now using their vanilla plants as collateral through a financing facility piloted by Tonga Development Bank. In Solomon Islands, shipping contracts have been used as security for loans. 


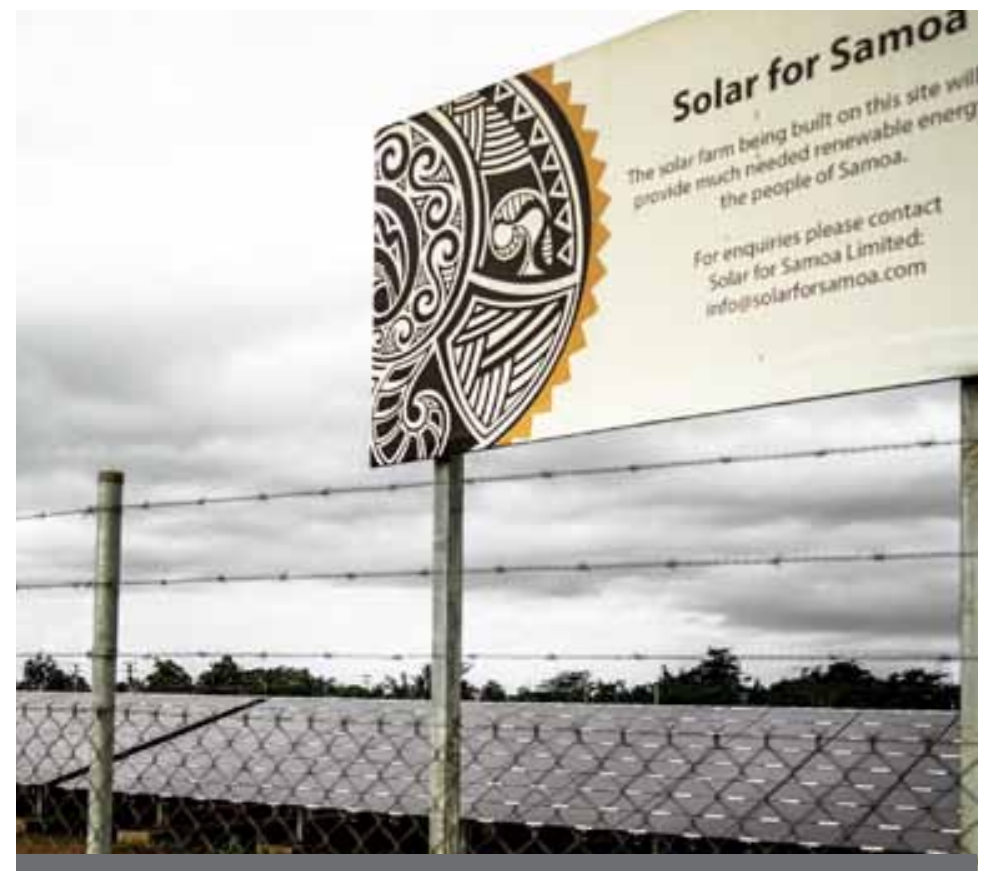

Samoa Solar Power Development Project. In July 2017, ADB made its first private sector energy investment in the regionmaking a $\$ 3$ million equity investment in an independent power producer for developing solar power at competitive prices in Samoa. The project will increase power generation capacity from 2.2 megawatts to 4.0 megawatts, increasing the affordability of solar power and lowering the country's dependence on fossil fuels.

PNG Microfinance Expansion and Financial Literacy Training. In Papua New Guinea, a large segment of the population have low literacy and numeracy rates and have never dealt with financial institutions. The project is helping people in remote areas manage their money wisely and make use of formal financial services to improve their lives.

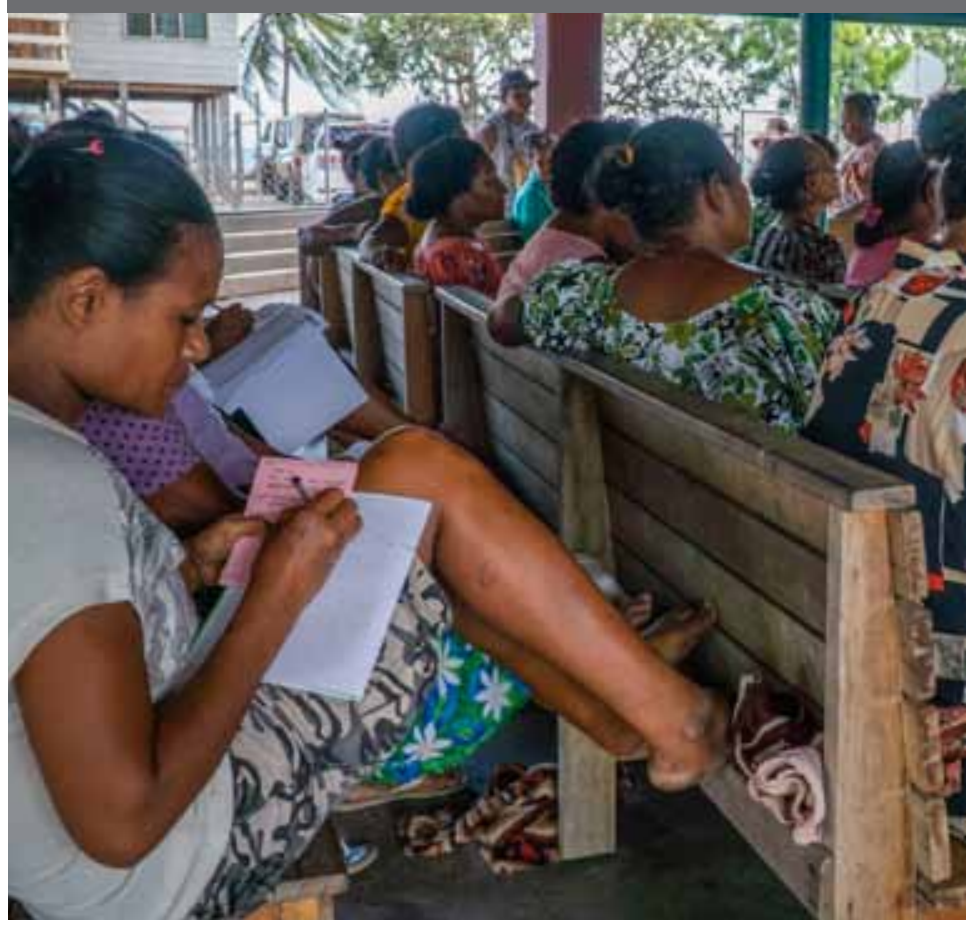

PNG National Airports Corporation. ADB is providing transaction advisory services for a public-private partnership that will enable PNG's National Airports Corporation to select a concessionaire to develop a new international passenger terminal at Jacksons International Airport in Port Moresby. The new terminal will be capable of meeting passenger demand for the next 30 years.
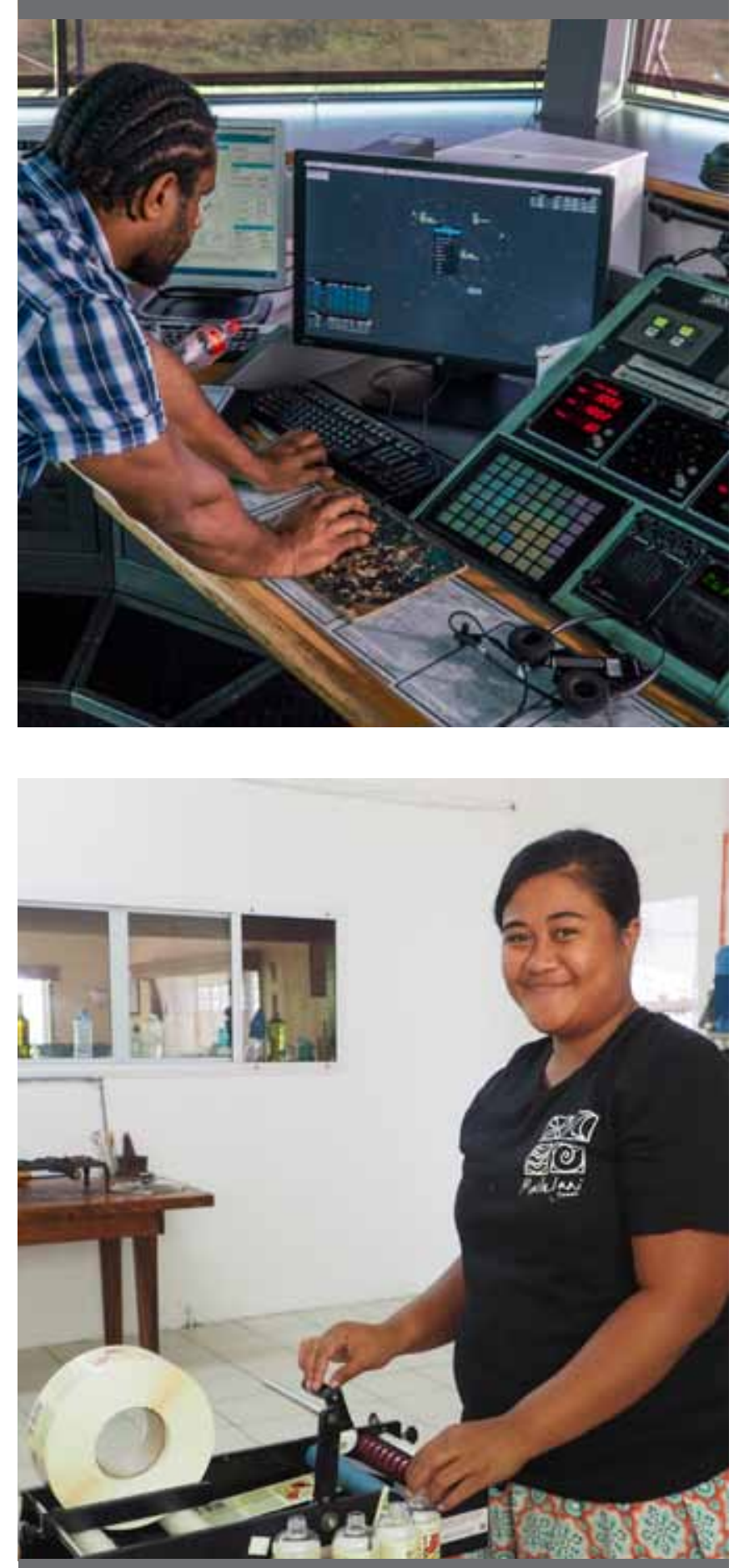

Samoa Agribusiness Support Project. ADB entered into a risk-sharing arrangement with four banks that supported agribusinesses in Samoa obtain commercial finance. The project also provides seed capital and advisory services to local agribusinesses for business expansion. 


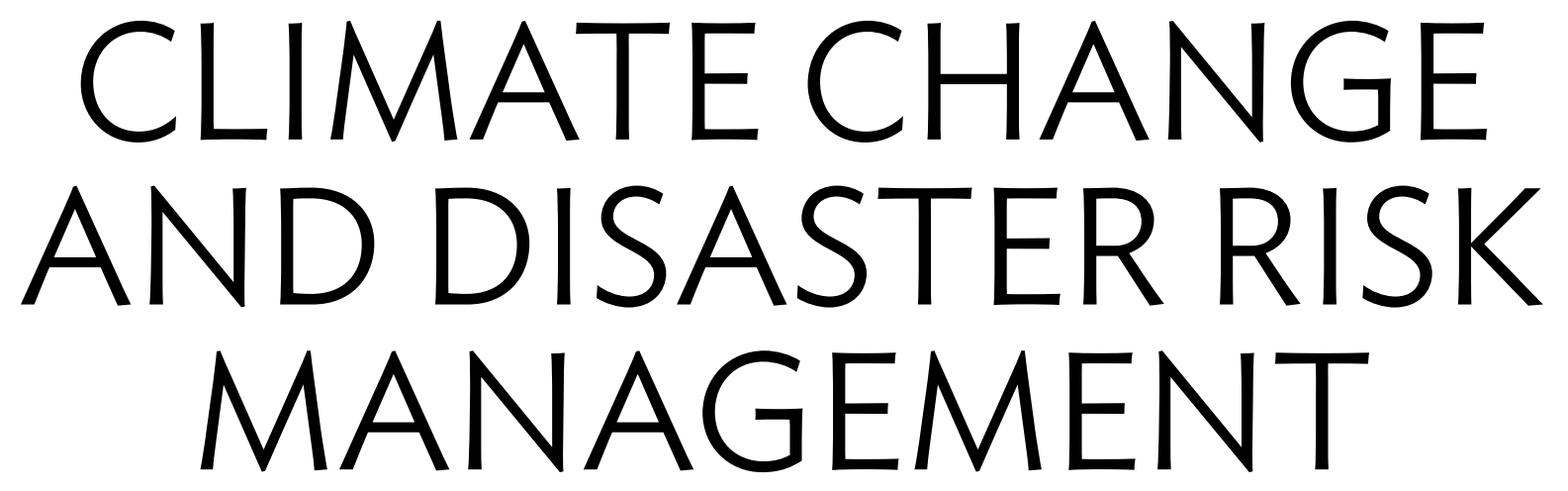

Disasters can erode years of development progress by damaging infrastructure and diverting financial and human resources toward response, recovery, and reconstruction efforts. Pacific DMCs are among the most vulnerable to natural disasters and the effects of climate change, Given their location along the tropical cyclone belt and the Pacific Ring of Fire. The small size, remoteness, and fragility of Pacific economies pose additional challenges for responding to disasters-emphasizing the need for resilience planning at all levels of the development process.

ADB is helping to address the root causes of vulnerability and fragility in its Pacific DMCs. Projects are increasing resilience to climate change, disasters, and economic shocks by (i) financing climate-resilient infrastructure; (ii) improving disaster risk reduction, response, and management; (iii) promoting low-carbon development; (iv) increasing access to climate and disaster risk finance; and ( $v$ ) building core capacities to plan for and respond to climate change and disasters.

\section{Achieving Results}

ADB is actively assisting its Pacific DMCs mobilize resources for climate change mitigation and adaptation. Since 2015, ADB has helped five Pacific DMCs - the Cook Islands, Fiji, Kiribati, Nauru, and Tongaaccess and administer $\$ 133$ million in concessional financing from the Green Climate Fund (GCF) to build climate-proof infrastructure and new renewable energy generation capacity across the Pacific, and to improve business processes of power utilities.

ADB also prepares climate change risk assessments for all its investments in the Pacific, and has provided $\$ 40$ million in disastercontingent financing to the Cook Islands, Palau, Samoa, Tonga, and Tuvalu. Contingent financing facilities have delivered emergency resources in the aftermath of disasters.

\section{Looking Forward}

ADB's technical assistance will continue to strengthen knowledge and capacities for Pacific DMCs to plan and prepare for climate change. A priority is to help integrate climate change and disaster risk management considerations into national development plans and programs. Doing so will strengthen preemptive measures and improve local capacities for responding to disasters. Engaging communities and local governments in resiliencebuilding activities is increasingly important. ADB will continue to mobilize concessional financing for climate change and disaster risk management, while working with development partners to pool resources across the region.

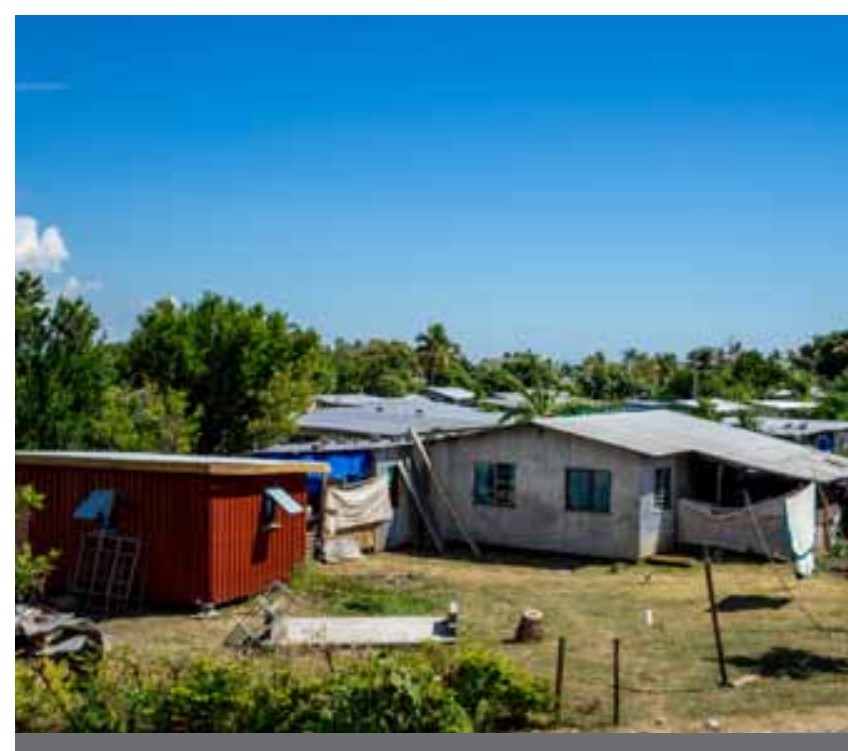

Fiji Emergency Assistance After Tropical Cyclone Winston. In February 2016, Tropical Cyclone Winstonthe second most powerful storm on record-destroyed 495 schools, 88 health facilities, and more than 30,000 homes in Fiji. ADB mobilized $\$ 50$ million within weeks of the disaster to help reconstruct schools to disasterresilient engineering standards. 


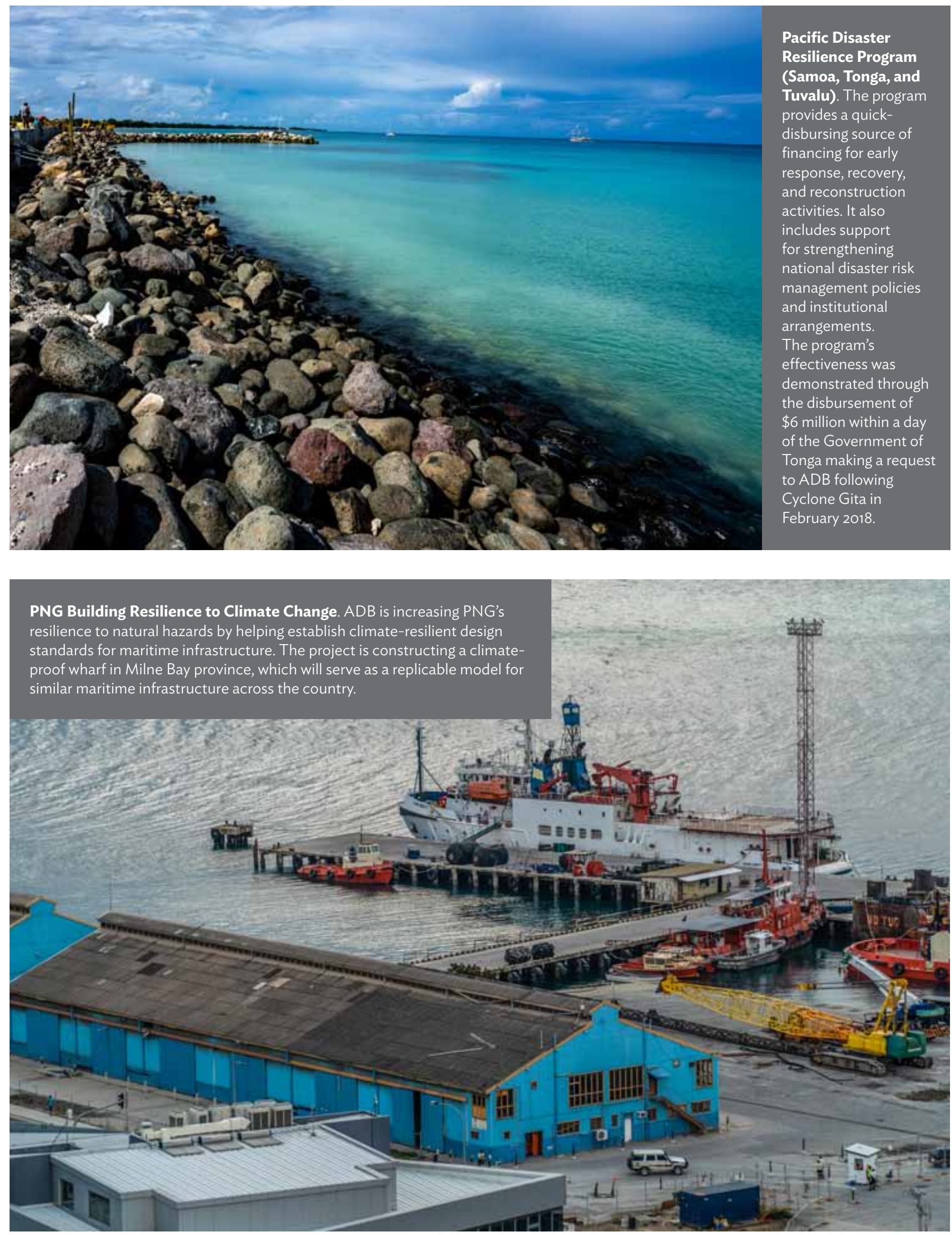




\section{GENDER INCLUSIVENESS}

Empowering women is key to achieving inclusive, resilient, and sustainable development in the Pacific. Despite progress in advancing gender equality in many Pacific DMCs, much work remains to address the poverty and inequality that women and girls continue to face across the Pacific. Women still have limited representation in decision-making structures, and violence against women remains a concern in several Pacific DMCs.

ADB is helping Pacific DMCs to (i) incorporate gender-inclusive projects in all sectors to create economic opportunities for women and girls, (ii) provide targeted training and skills development opportunities, (iii) support women in leadership and decision-making roles, (iv) enable women to reduce unpaid work responsibilities, (v) increase the resilience of women and girls to external shocks, and (vi) promote policy dialogue on gender inclusiveness and equality.

\section{Achieving Results}

ADB's assistance across multiple sectors has delivered significant benefits for women in the Pacific. Enhancing mobility and reducing travel time have led to better access to services, more livelihood opportunities, and higher incomes for women. ADB's education and skills training programs have helped women find jobs in nontraditional sectors, such as the repair and maintenance of solar power systems. Financial literacy programs supported by ADB have reached close to 100,000 women, enabling them to open bank accounts, adopt sound saving habits, and practice financial discipline. ADB's water, energy, health, and ICT projects have reduced many of the hardships faced by women and girls in the region.

\section{Looking Forward}

ADB will continue to mainstream gender considerations into project designs; support policy dialogue on gender equality; and build the capacity of governments to develop, deliver, and monitor gender equality results, in close collaboration with development partners and regional organizations.

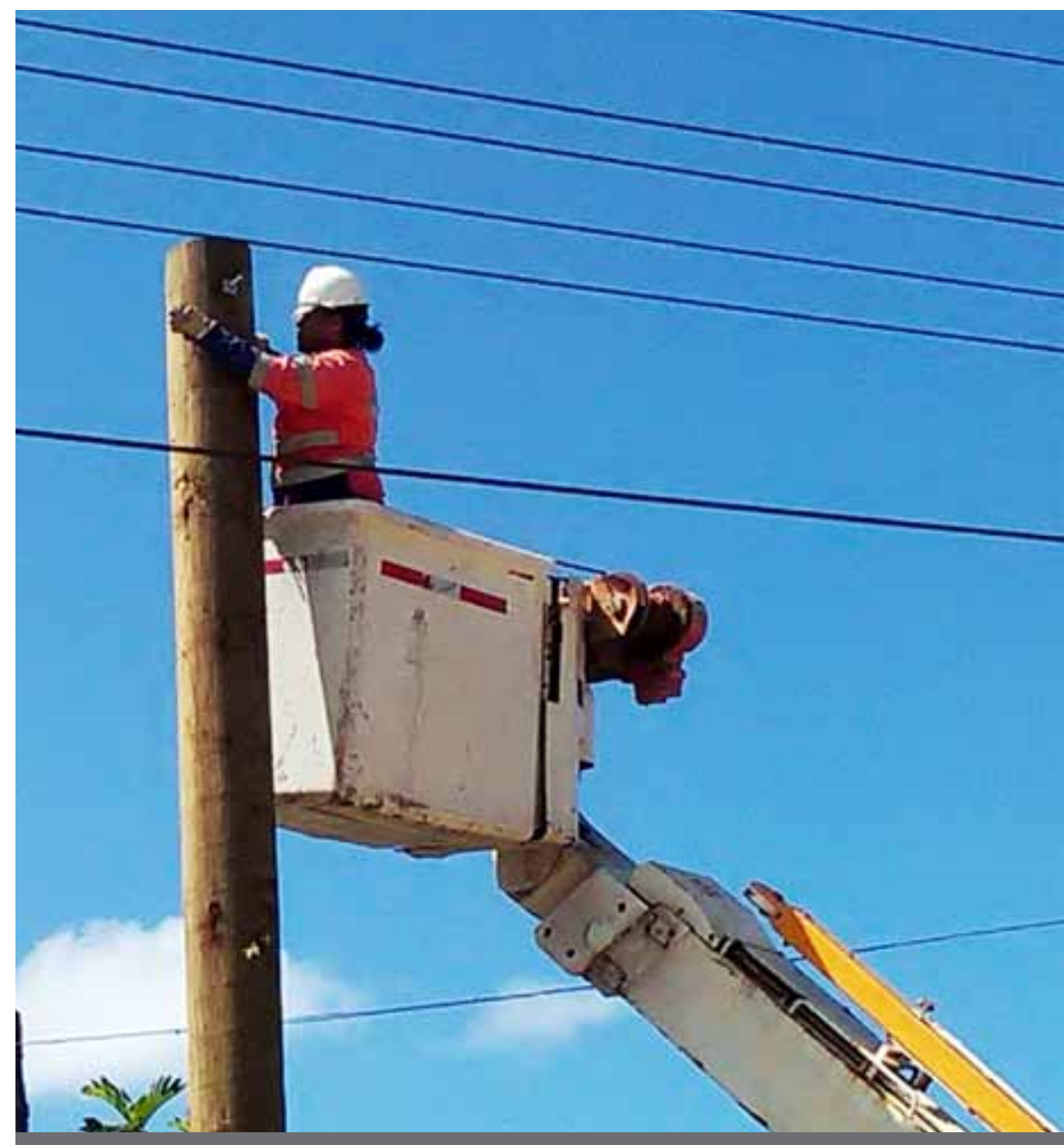

Nontraditional Careers for Women. In Tonga, ADB's assistance enables women to receive training for unconventional jobs, such as serving as lines women for power utilities. Armed with unique skills, these women are able to earn higher incomes and serve as role models for other women and girls in their communities. 

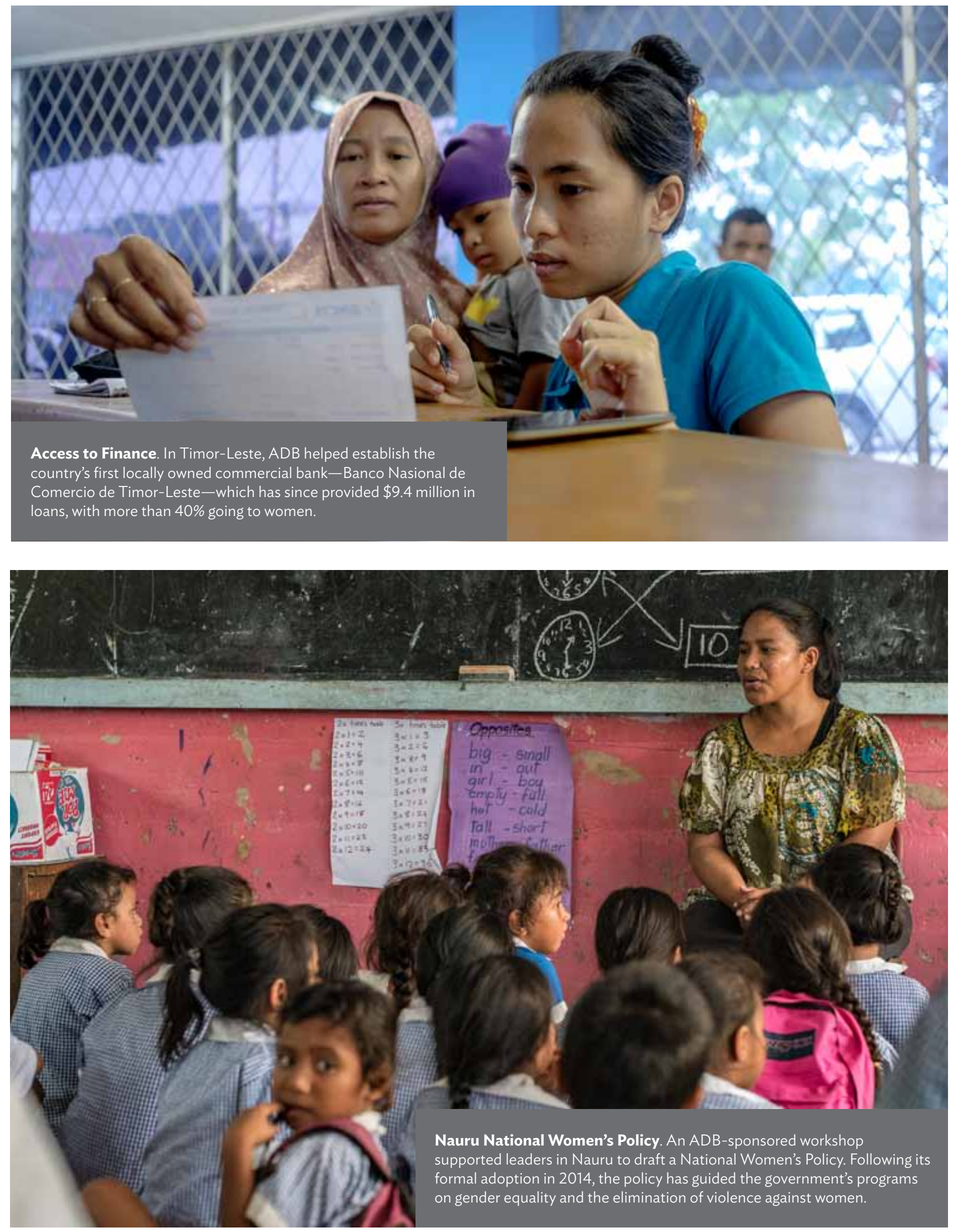


\section{REGIONAL \\ COOPERATION

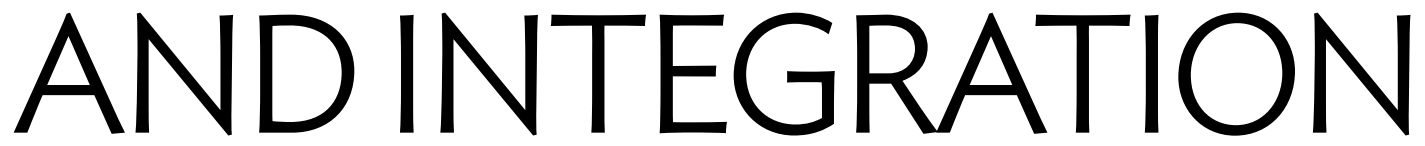

Regional cooperation is essential for addressing many of the challenges that are facing Pacific DMCs. Collaboration is one of the strategies to overcome the constraints associated with their remoteness, small economies, and vulnerability to disasters and climate change.

Many of ADB's flagship technical assistance programs for the Pacific are regional in their coverage and promote knowledge sharing among Pacific DMCs. Some examples include the Pacific Regional Infrastructure Facility, the Pacific Financial and Technical Assistance Center, the Pacific Economic Management Program, and PSDI. Each of these initiatives pool resources, including knowledge, technical capacity, and finance, to address shared challenges and identify solutions anchored on regional cooperation and benefits.

\section{Achieving Results}

Since 2009, ADB has successfully mobilized more than $\$ 160$ million in additional financing for regional cooperation projects and programs in the Pacific, over and above the funds which would otherwise have been made available for the region through individual country allocations.

Regional cooperation has enabled the Pacific DMCs to accomplish common goals that would not have been technically or financially viable on an individual country basis. For example, sharing costs of installing a submarine fiber-optic cable made such projects possible for small countries such as the Cook Islands and Nauru. Bulk procurement of vaccines is enabling the Pacific DMCs to benefit from economies of scale in improving health coverage and higher immunization rates.

\section{Looking Forward}

ADB will continue to prioritize projects that promote regional cooperation and integration in areas of common interest. Processing interventions on a regional basis can be more efficient and cost-effective than the use of country-by-country approaches. In addition to supporting new maritime trade and transport links, ADB is exploring options to assist Pacific DMCs take a regional approach to improving the management of oceans and marine ecosystems.

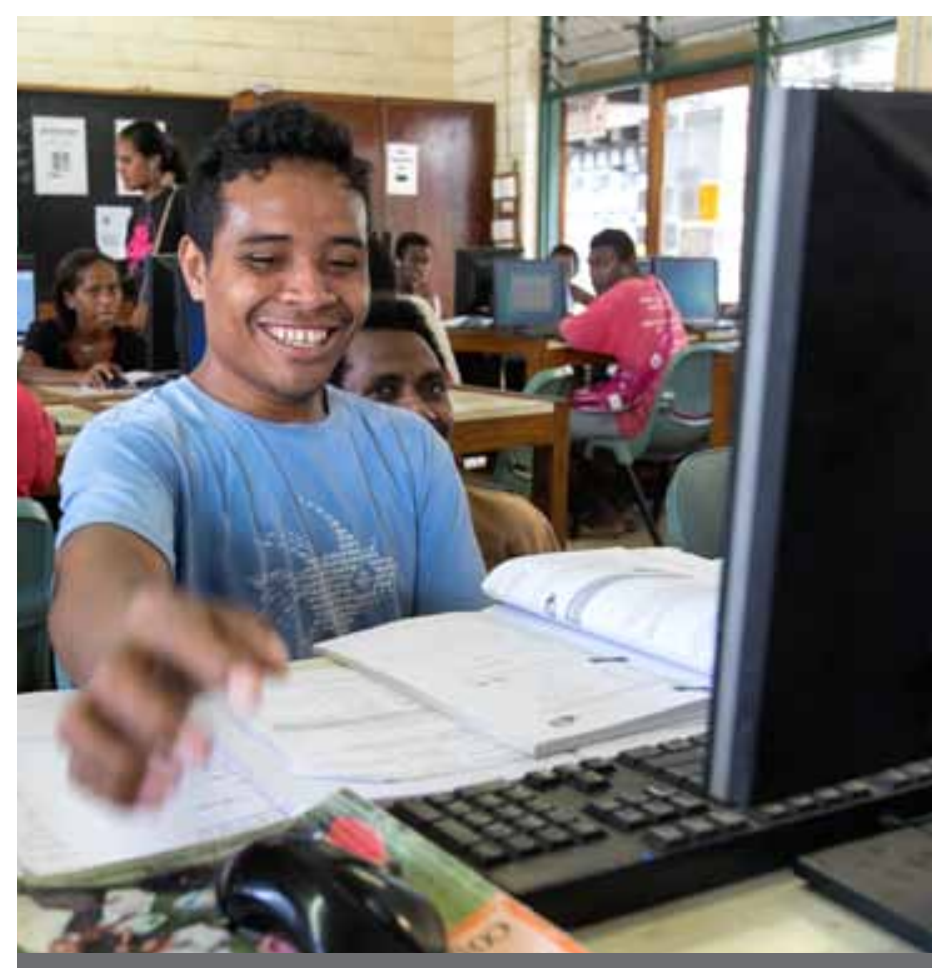

Promoting Regional Cooperation in the Education. ADB's Pacific higher education program has supported the University of the South Pacific expand its network of campuses and teaching across the region. ADB is also supporting the North Pacific countries of the Marshall Islands and the Federated States of Micronesia to work together to strengthen basic education curricula. 


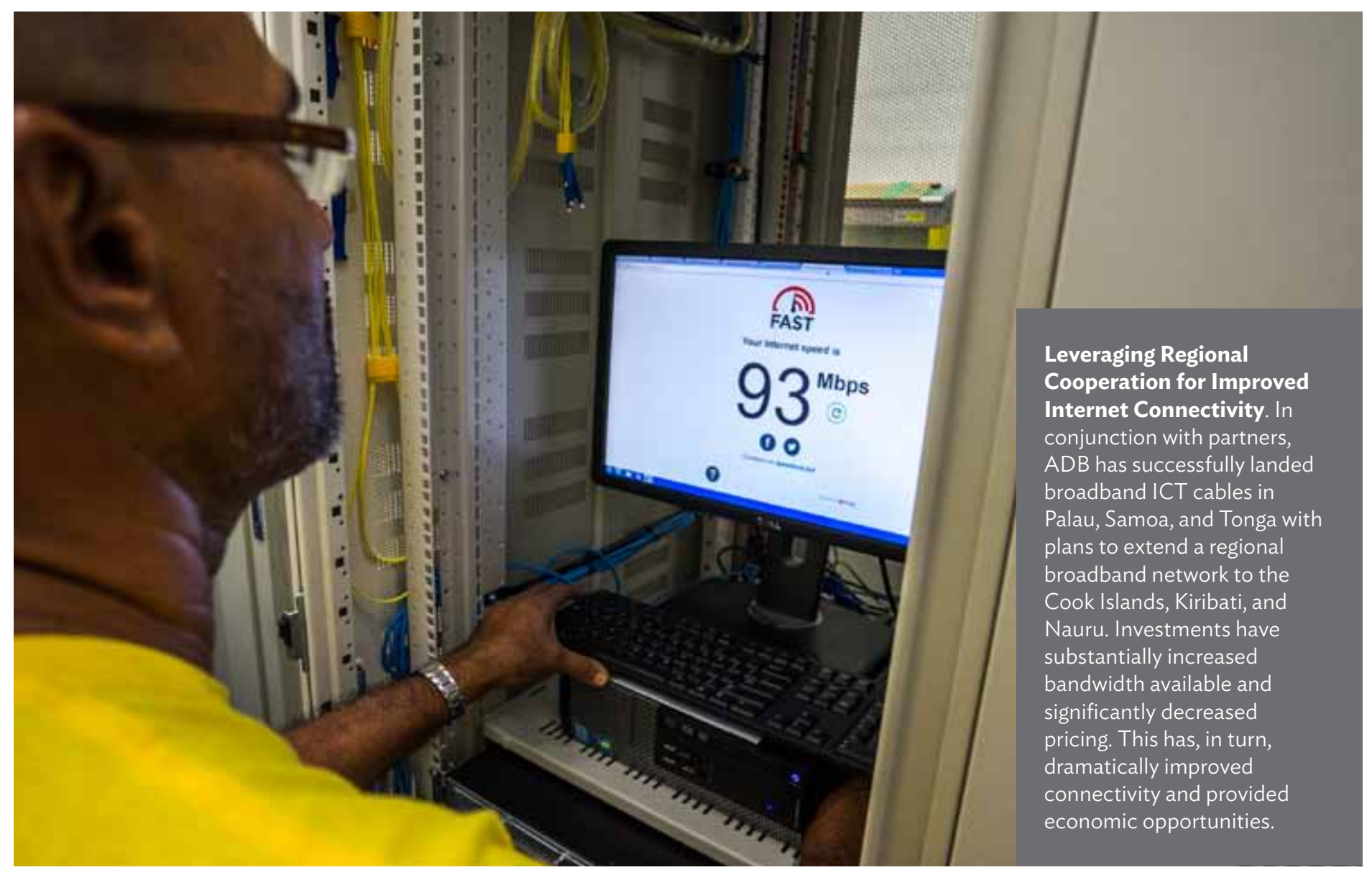

Building Resilience to Disasters through Regional Cooperation. ADB has provided contingent

financing to Samoa, Tonga, and Tuvalu to build resilience in these highly vulnerable countries. The program was effective in helping Tonga respond to Tropical Cyclone Gita in February 2018, providing resources to support the government's emergency response within days.

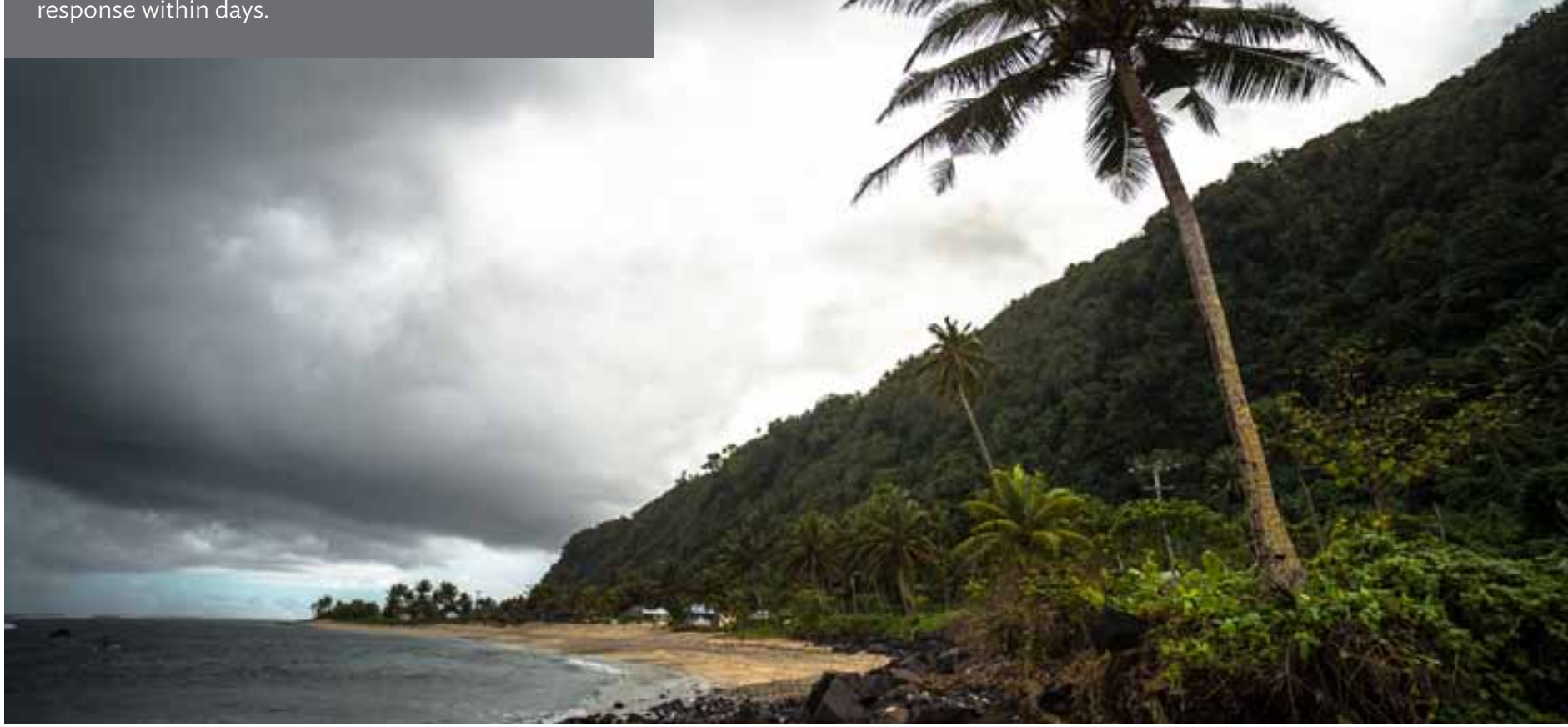




\section{COFINANCING}

ADB makes a special effort to attract cofinancing and coordinate external development assistance. In small countries, the harmonization of policies and procedures among development partners is essential, given limited local resources and institutional capacities. This approach enables ADB to support multipartner interventions in priority areas, including infrastructure, education, health, climate change, public sector management, and regional cooperation.

Cofinancing from bilateral and multilateral partners also assists ADB in packaging investments that are larger and more transformative than would be possible on an individual basis. Joint policy discussions between key partners and Pacific clients have provided for more flexible budget support financing for country-level reform efforts. The Pacific is also the only region globally where ADB has jointly cofinanced single contracts with other development partners, reducing transaction costs to Pacific countries.

\section{Achieving Results}

ADB's portfolio of active projects in Pacific DMCs at the end of 2018 amounted to almost $\$ 3$ billion, of which $\$ 0.4$ billion was administered cofinancing. Major cofinanciers in the Pacific include Australia, the European Union, the GCF, Japan, New Zealand, and the World Bank.

\section{Looking Forward}

$A D B$ will continue to explore collaboration with bilateral and multilateral development partners to magnify the impact of its assistance. In addition, ADB will expand its engagement with civil society organizations, universities, and think tanks so that it can promote longer-term policy thinking and analysis on Pacific development issues and opportunities.
Pacific Regional Infrastructure Facility (PRIF). In 2008, ADB, together with other development partners, established PRIF to support infrastructure development and maintenance in the Pacific. PRIF provides the technical expertise to identify and plan infrastructure projects for possible financing by one or more partners. PRIF also helps to ensure coordination among development partners while compensating for the shortage of technical capacity in small countries.

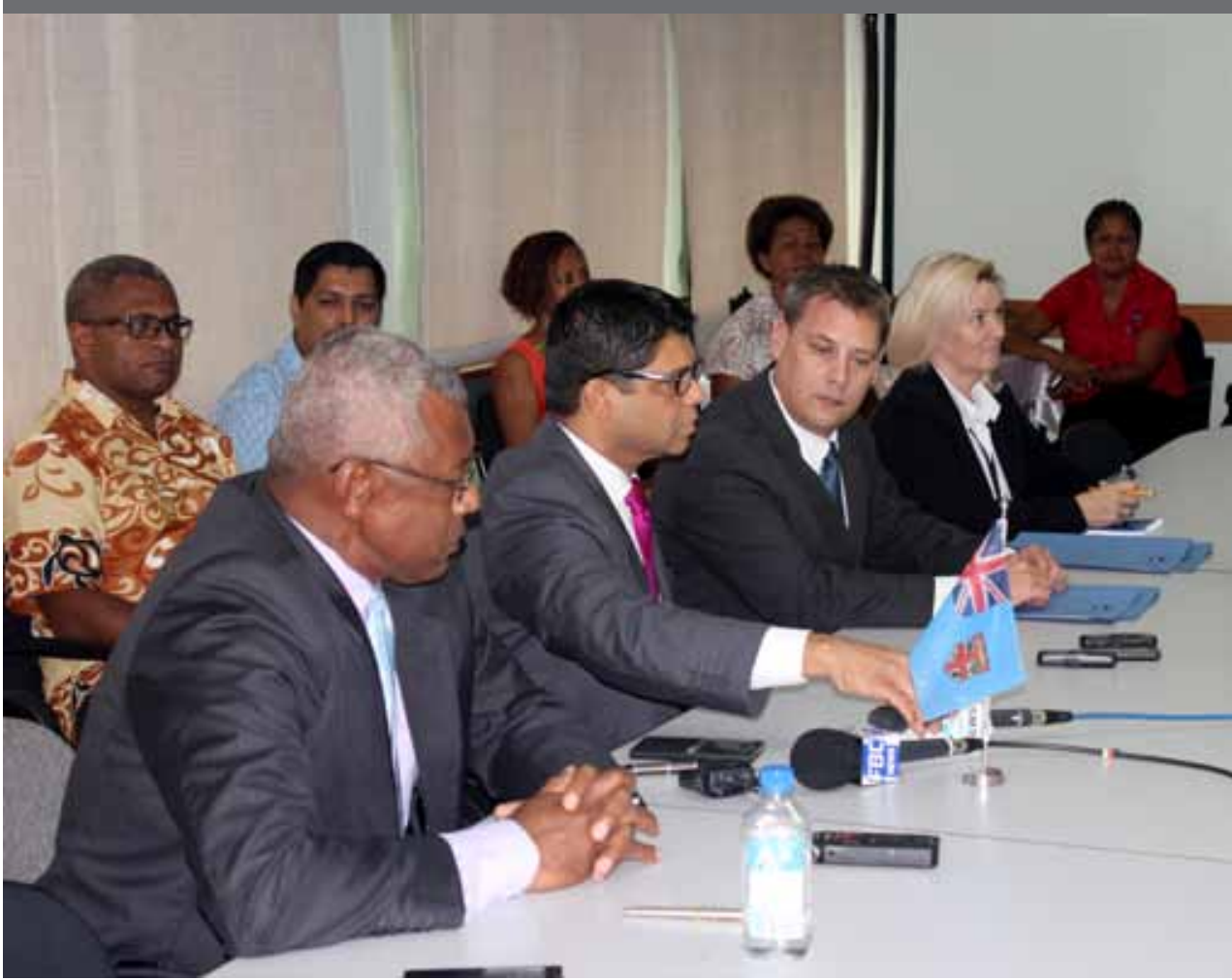




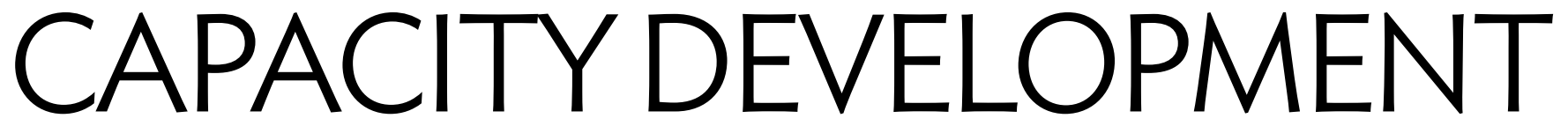

Pacific DMCs face numerous capacity constraints, owing in part to their remoteness and small populations. Their limited technical and administrative capacities are among the most significant constraints to sustainable development in the region.

ADB's technical assistance grants help bridge knowledge gaps and build expertise. In addition to deploying specialists to provide hands-on training and support, ADB sponsors scholarships and knowledge sharing activities to strengthen local capacities, including through workshops, seminars, study visits, and twinning arrangements. ADB also collects and shares lessons learned, from within and outside the Pacific, to strengthen capacities for project design, implementation, and maintenance.

\section{Achieving Results}

ADB's technical assistance is enabling governments in the Pacific to formulate coherent and forward-looking economic policies, to plan and implement sound projects, and to manage essential services. With access to ADB's technical expertise and exposure to the best practices of ADB's members, decisionmakers in the Pacific are better equipped to pursue their development goals and address their unique development challenges.

\section{Looking Forward}

ADB will continue to support institutional reforms and capacity building to ensure that investments deliver lasting development impacts. ADB will work with development partners, academia, and think tanks to facilitate cross-country learning and knowledge sharing, including on best practices from other regions.

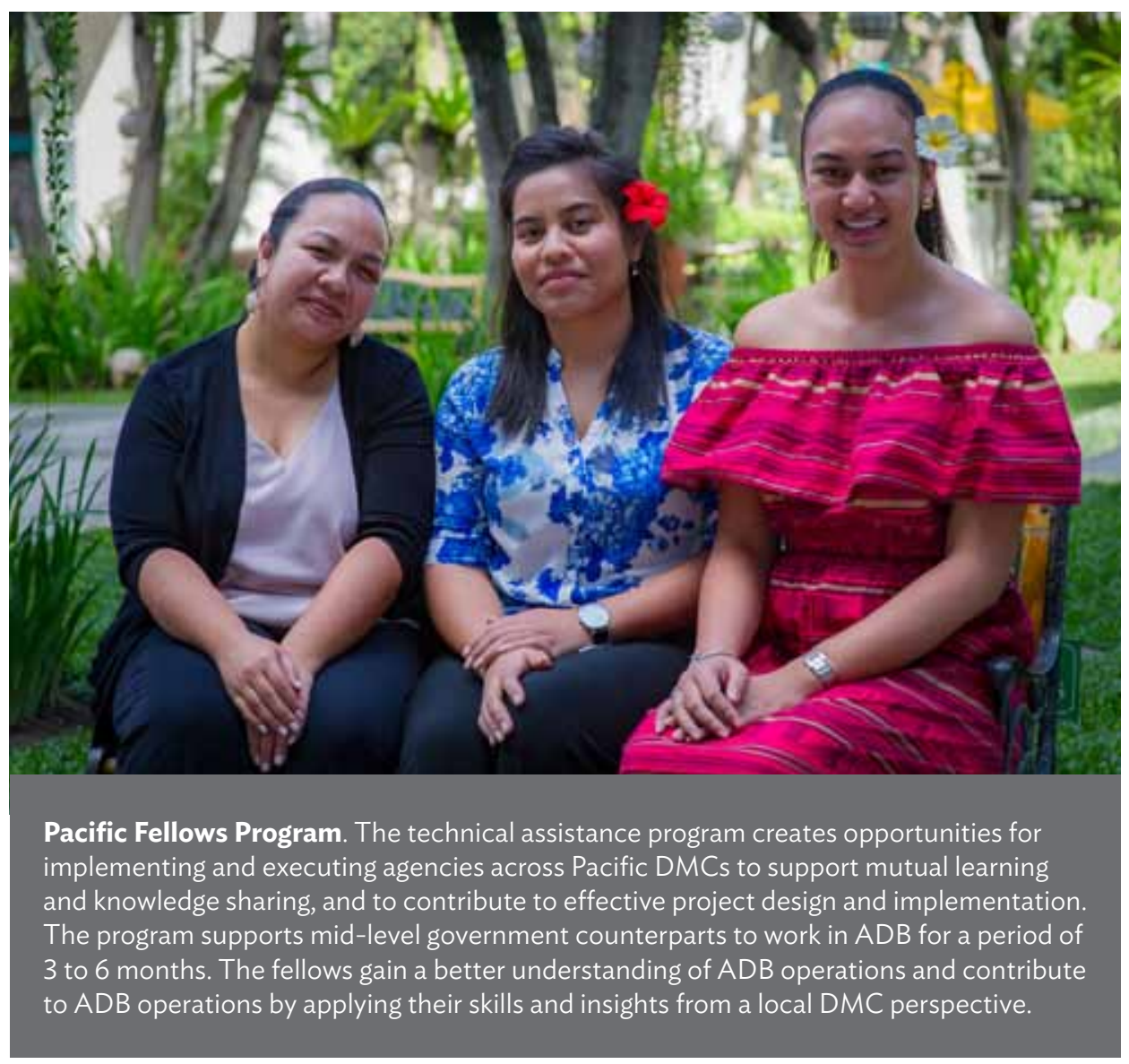




\section{PARTNERSHIPS}

ADB's partnerships with bilateral and multilateral agencies and regional organizations have become a prominent feature in the Pacific. The bank's projects and technical assistance, at both the country and regional levels, have benefited greatly from the cofinancing expertise and knowledge provided by development partners active in the region.

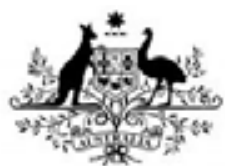

Australian Government

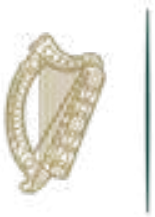

Rialtas na hÉireann

Government of Ireland
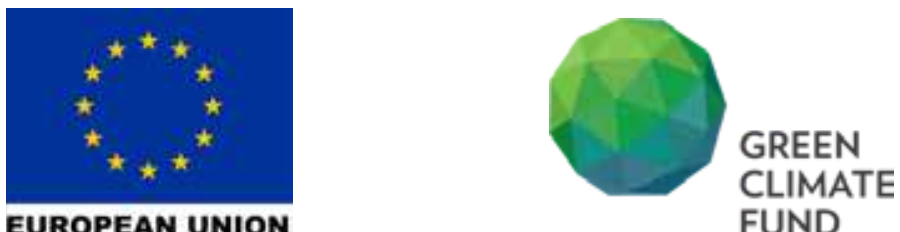

FUND

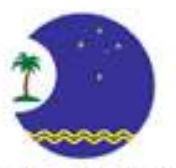

PACIFIC ISLANDS FORUM SECRETARIAT

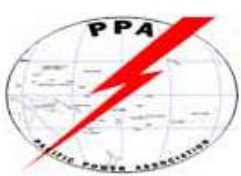

PACIFIC POWER ASSOCIATION
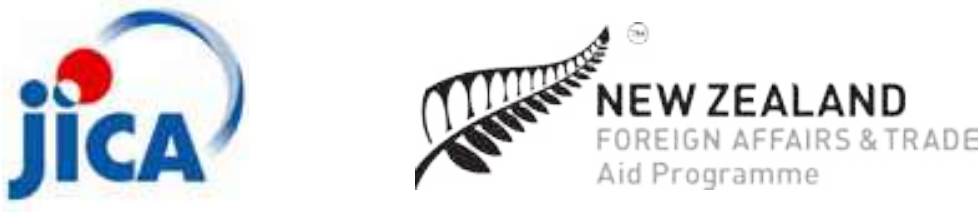

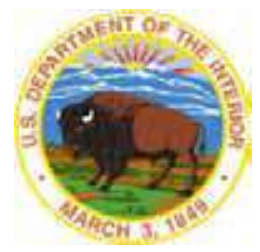

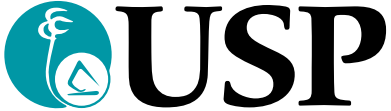

THE UNIVERSITY OF THE SOUTH PACIFIC

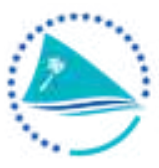

Pacific

Community

Communauté du Pacifique

${ }^{*}$ The partners identified here represent only some of the numerous development partners that have jointly supported ADB operations in the Pacific over the past 5 decades. 


\section{ADB OFFICES IN THE PACIFIC}

ADB has 15 offices in the Pacific - 2 regional offices, 2 resident missions, and 11 country offices.

\author{
Pacific Liaison and Coordination Office \\ Level 20, 45 Clarence Street \\ Sydney, NSW 2000, Australia \\ Tel +61282709444 \\ adbplco@adb.org

\section{Pacific Subregional Office} \\ 5th Floor, Ra Marama Building \\ 91 Gordon Street, Suva, Fiji \\ Tel +6793318101 \\ adbspso@adb.org
}

\section{Papua New Guinea Resident Mission}

Level 2-Burns Philp Haus

Corner of Musgrave Street \& Champion Parade

P.O. Box 1992, Port Moresby

National Capital District, Papua New Guinea

Tel +6753210400

Fax +6753210407

adbpnrm@adb.org

\section{Timor-Leste Resident Mission}

ADB Building

Rua Cabo Verde No 16, Posto Administrativo

Vera Cruz, Suco Motael, Aldeia Halibur

Dili, Timor-Leste

Tel +6703324801

Fax +6703324132

adbtlrm@adb.org

\section{Cook Islands}

Nikao, Rarotonga

P.O. Box 3338

Cook Islands

Tel + 68222697

Federated States of Micronesia

P.O. Box PS-158

Palikir, Pohnpei 96941

Federated States of Micronesia

Tel +6913202640

Fax +6913202597

\section{Kiribati}

Unit 4, Tiarite Kwong Plaza

Main Street Bairiki

Tarawa, Kiribati

Tel +686 22040/22041

\author{
Marshall Islands \\ c/o The Marshall Islands Resort Hotel \\ P.O. Box 3279 \\ Mieco Beach Front, Amata Kabua Blvd. \\ Majuro, MH 96960 \\ Marshall Islands \\ Tel +692 6252525
}

\section{Nauru}

Government Building

Yaren District, NRU68

Nauru

Tel + 6745573133

\section{Palau}

Room 209, PDC Building

Koror, Palau 96940

Tel +680 7751990

\section{Samoa}

Level 7 Central Bank Building

Apia, Samoa

Tel +685 21900/21424

Mob +685 7739344

\section{Solomon Islands}

Level 1, Heritage Park Commercial Building

Mendana Avenue

Honiara, Solomon Islands

Tel +677 23333

\section{Tonga}

c/o Ministry of Finance and National Planning

1st Floor, Royco Building

P.O. Box 87, Nuku'alofa, Tonga

Tel +67628290 (Reception)

$\mathrm{Tel}+67628735$ (SCCO)

\section{Tuvalu}

Partnership House

Vaiaku, Funafuti, Tuvalu

Tel +68820610

\section{Vanuatu}

Level 5, Reserve Bank Building

Rue Emile Mercet

P.O. Box 246

Port Vila, Vanuatu

Tel +678 23610 


\section{ADB Operations in the Pacific}

Operations of the Asian Development Bank (ADB) in the Pacific date back to 1969 and have since grown rapidly in line with interconnected needs. Development partnerships, projects, and other initiatives aim to strengthen infrastructure and services, build human and institutional capacity, and increase the resilience of communities across the region. This publication commemorates over 50 years of partnership in the region as Fiji becomes the first Pacific developing member country to host the 2019 ADB Annual Meeting. Highlights include the evolution of core operational areas, recent successes, and emerging areas for collaboration and support.

\section{About the Asian Development Bank}

ADB is committed to achieving a prosperous, inclusive, resilient, and sustainable Asia and the Pacific, while sustaining its efforts to eradicate extreme poverty. Established in 1966, it is owned by 68 members -49 from the region. Its main instruments for helping its developing member countries are policy dialogue, loans, equity investments, guarantees, grants, and technical assistance.

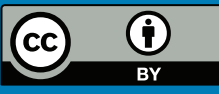

(C) 2019 Asian Development Bank

6 ADB Avenue, Mandaluyong City, 1550 Metro Manila, Philippines

Tel +632632 4444; Fax +6326362444

www.adb.org

Some rights reserved. Published in 2019.

Printed in the Philippines.

ISBN 978-92-9261-574-1 (print), 978-92-9261-575-8 (electronic)

Publication Stock Number: ARM190082-2

DOI: http://dx.doi.org/10.22617/ARM190082-2

The views expressed in this publication are those of the authors and do not necessarily reflect the views and policies of the Asian Development Bank (ADB) or its Board of Governors or the governments they represent.

ADB does not guarantee the accuracy of the data included in this publication and accepts no responsibility for any consequence of their use. The mention of specific companies or products of manufacturers does not imply that they are endorsed or recommended by ADB in preference to others of a similar nature that are not mentioned.

By making any designation of or reference to a particular territory or geographic area, or by using the term "country" in this document, ADB does not intend to make any judgments as to the legal or other status of any territory or area.

This work is available under the Creative Commons Attribution 3.0 IGO license (CC BY 3.0 IGO)

https://creativecommons.org/licenses/by/3.0/igo/. By using the content of this publication, you agree to be bound by the terms of this license. For attribution, translations, adaptations, and permissions, please read the provisions and terms of use at https:// www.adb.org/terms-use\#openaccess.

This CC license does not apply to non-ADB copyright materials in this publication. If the material is attributed to another source, please contact the copyright owner or publisher of that source for permission to reproduce it.

ADB cannot be held liable for any claims that arise as a result of your use of the material.

Please contact pubsmarketing@adb.org if you have questions or comments with respect to content, or if you wish to obtain copyright permission for your intended use that does not fall within these terms, or for permission to use the ADB logo.

Corrigenda to ADB publications may be found at http://www.adb.org/publications/corrigenda.

Note:

In this publication, “\$” refers to United States dollars.

All images are from ADB.

ADB recognizes "East Timor" as Timor-Leste. 